\title{
Archeological Testing of Sites 41WB437 and 41WB438 Webb County, Texas
}

James T. Abbott

Texas Department of Transportation

Follow this and additional works at: https://scholarworks.sfasu.edu/ita

Part of the American Material Culture Commons, Archaeological Anthropology Commons, Environmental Studies Commons, Other American Studies Commons, Other Arts and Humanities Commons, Other History of Art, Architecture, and Archaeology Commons, and the United States History Commons

Tell us how this article helped you.

This Article is brought to you for free and open access by the Center for Regional Heritage Research at SFA ScholarWorks. It has been accepted for inclusion in Index of Texas Archaeology: Open Access Gray Literature from the Lone Star State by an authorized editor of SFA ScholarWorks. For more information, please contact cdsscholarworks@sfasu.edu. 


\section{Archeological Testing of Sites 41WB437 and 41WB438 Webb County, Texas}

\section{Licensing Statement}

This is a work produced for the Texas Department of Transportation (TxDOT) by the report producer. TxDOT and the report producer jointly own all rights, title, and interest in and to all intellectual property developed under TXDOT's contract with the report producer. The report may be cited and brief passages from this publication may be reproduced without permission provided that credit is given to both TxDOT and the report producer. Permission to reprint an entire chapter, section, figures or tables must be obtained in advance from either the Supervisor of the Archeological Studies Branch, Environmental Affairs Division, Texas Department of Transportation, 125 East 11th Street, Austin, Texas, 78701 or from the report producer. 


\title{
Archeological Testing of Sites $41 \mathrm{WB} 437$ and $41 \mathrm{WB} 438$ Webb County, Texas
}

\author{
By \\ James T. Abbott
}

1997

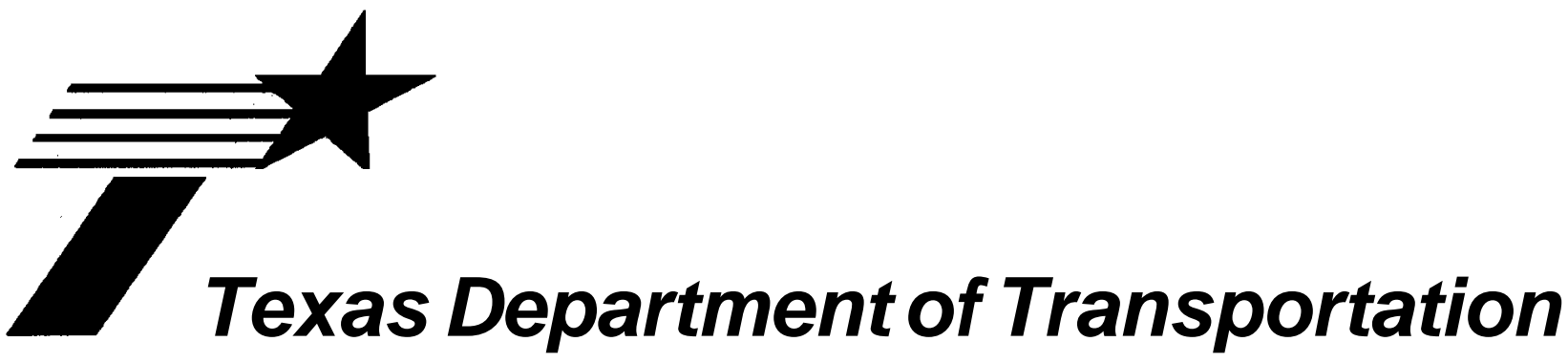


ARCHEOLOGICAL TESTING OF SITES $41 \mathrm{WB} 437$ and $41 \mathrm{WB} 438$

W E B B COUNTY, TEXAS

CS : 0038-01-028

by

James T. Abbott

Archeology Studies Program

Environmental Affairs Division

Texas Department of Transportation

1997 


\section{ACKNOWLEDGEMENTS}

Investigation of Sites $41 \mathrm{WB} 437$ and $41 \mathrm{WB} 438$ was conducted with the assistance of many individuals. Melissa Montemayor, Environmental Coordinator for the Laredo District, coordinated all aspects of the project at the local level. Her assistance was invaluable in getting the project completed in a timely and efficient manner. Jerry Henderson of the Environmental Affairs Division, Texas Department of Transportation, served as Project Archeologist during the field phase. Jim Abbott of the ENV staff served as Project Geomorphologist and conducted the archeological analysis and reporting of the project after Ms. Henderson left TxDOT. Jesus "Chuy" Gonzalez, another ENV staff member, participated in the field investigation and in laboratory processing and analysis of recovered artifacts. Nancy Kenmotsu, of ENV, also worked briefly at the site and participated in several valuable discussions during the analytical phase. Ann Irwin, Al McGraw, and Lain Ellis of the ENV staff also provided valuable comments during analysis and report preparation. Laredo District employees who provided assistance in the field include Eloy Juarez, Iris Flores, Juan Garza, David Enriquez, and Rodolfo Amesquita, Jr. The backhoe operator was J ose Esparza, Jr., and the location of test units was mapped by surveyors Hector Cantu and Jorge Rodriguez.

Submission of radiocarbon samples was coordinated through the Center for Archeological Research, University of Texas at San Antonio. Dr. Britt Bousman, Dr. Robert Hard, and the staff of UTSA-CAR are thanked for their assistance in this regard. Radiocarbon samples were processed by Beta Analytic, Inc, of Miami, Florida, and accelerator mass spectrometer radiocarbon assays were determined at the Lawrence Livermore National Laboratory. Finally, Dr. Tom Gustavson of the Texas Archeological Research Lab, University of Texas at Austin, made an extended field visit during trenching of $41 \mathrm{WB} 437$ and $41 \mathrm{WB} 438$ and contributed a number of pertinent observations about the stratigraphy of the sites. 


\begin{abstract}
Archeological sites 41WB437 and 41WB438 are two prehistoric sites situated on opposing terraces of San Idelfonso Creek at the crossing of U.S. Highway 83, approximately $7.5 \mathrm{~km}$ south of Laredo, Texas, and $0.6 \mathbf{~ k m}$ upstream from the confluence of the stream and the Rio Grande River. Site $41 \mathrm{WB} 438$ is characterized by a relatively dense accumulation of lithic debris and occasional groundstone fragments scattered across a broad alluvial terrace on the south side of the stream. Site 41WB437 is characterized by a much sparser scatter of cultural material on the north terrace. Both sites, but in particular 41WB438, have been heavily modified at the surface by historic activity. Archeological significance testing of the portion of these two sites in the R-OW of US Highway 83 was conducted by TxDOT personnel in late March and early April, 1997, using a combination of mechanically-excavated and hand-excavated units.
\end{abstract}

The results of testing indicate that site $41 \mathrm{WB} 437$ is underlain by thick, silty late Holocene alluvial unit that contains a number of ephemeral, relatively high integrity cultural strata to depths of at least $2 \mathrm{~m}$ below the ground surface. While the cultural material associated with these occupations is not particularly abundant, the presence of preserved burned rock features with associated charcoal, bone, shell, and lithic debris suggests that the site has the potential to yield important subsistence and technological information relevant to discrete, short term episodes of cultural activity. Therefore, the site is considered eligible for nomination to the National Register of Historic Places and for designation as a Texas State Archeological Landmark. Because avoidance is impractical, a mechanically-assisted block excavation focused on exposure and documentation of one or more broad occupation surfaces in the upper $1.5 \mathrm{~m}$ of the deposit is recommended to mitigate impacts to the site.

Site 41WB438, in contrast, consists of a thin veneer of the same late Holocene alluvial fill resting on a much older, culturally sterile alluvial fill. Cultural material is lightly dispersed through the upper $50 \mathrm{~cm}$ of the terrace fill, but appears to be in poor stratigraphic context. However, it is possible that intact deposits are preserved in the unexamined portion of the site, which lies to the west of the R-O-W. Therefore, while the site cannot be ruled ineligible, no significant impact to the site's data potential will occur as a result of planned construction activities, and no further archeological work is recommended within the $\mathrm{R}-\mathrm{O}-\mathrm{W}$. 


\section{TABLE OF CONTENTS}



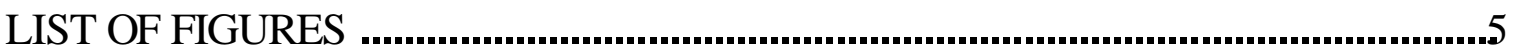

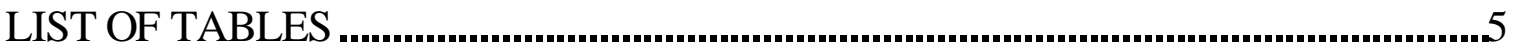

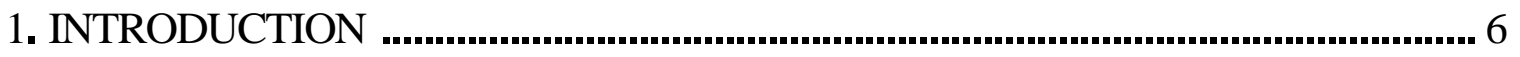

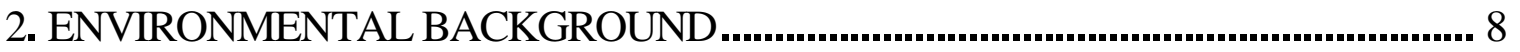

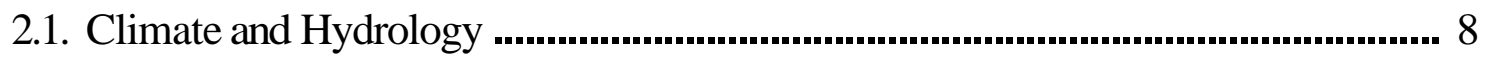

2.2. Physiography and Geology ............................................................................

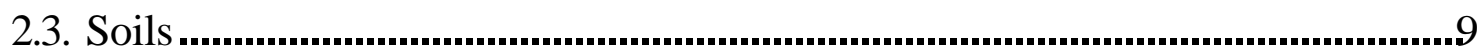

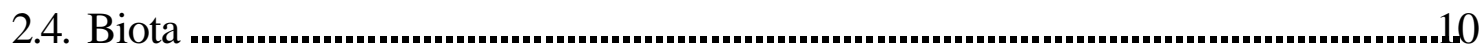

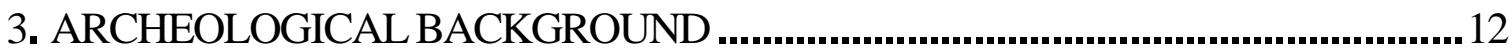

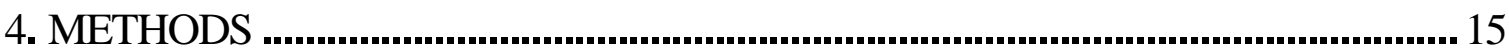



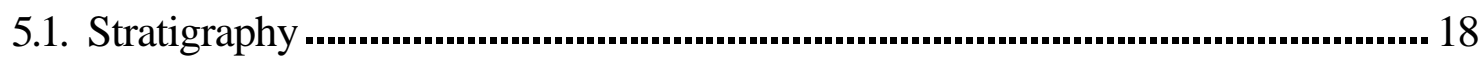

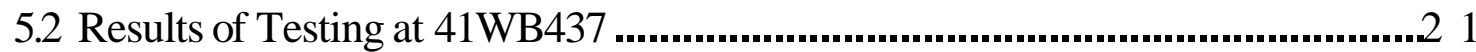

5.2.1 Test Unit Descriptions ............................................................................ 21

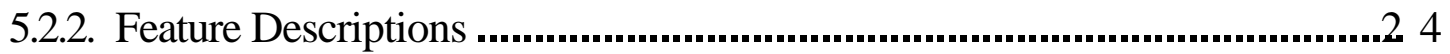

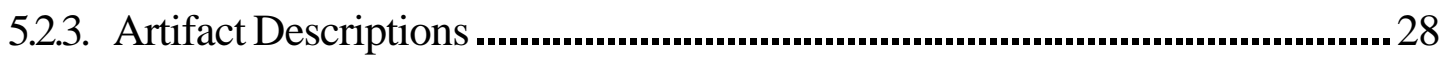

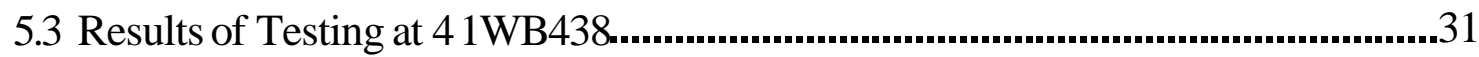

5.3.1. Test Unit Descriptions........................................................................................... 31

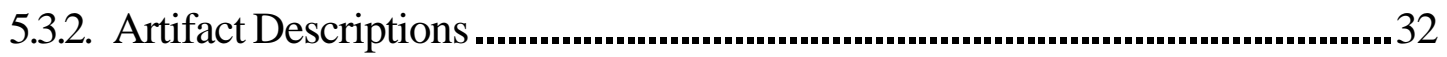

6. SUM M ARY, ELIGIBILITY DETERM INATIONS, AND RECOMMENDATIONS

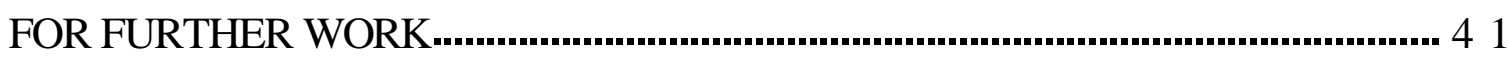

6.1 Summary and Eligibility Determinations.........................................................41

6.2. Recommendations for Further Work ............................................................... 42

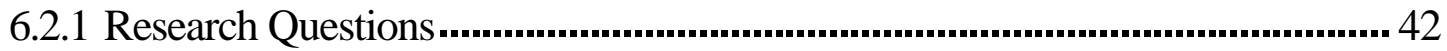

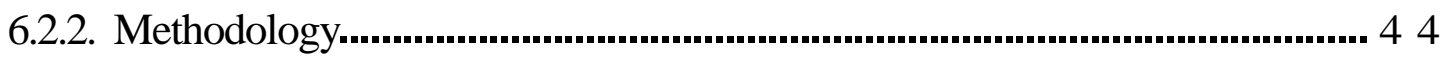

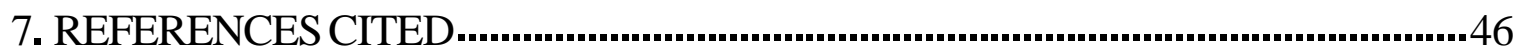

Appendix I: Backhoe Trench Descriptions .................................................................... 50 


\section{LIST OF FIGURES}

Figure 1: General location of 41WB437 and 41WB438

Figure 2: Geomorphic sketch map of the vicinity of 41WB437 and 41WB438 ................9

Figure 3: Stereopair imageof the U.S. 83 crossing at San Idelfonso Creek 10

Figure 4: Location of test units. backhoe trenches. and physical features on 41WB437 and 41WB438 16

Figure 5: Schematic stratigraphic cross-section of the San Idelfonso valley 19

Figure 6: Sedimentation rates for the fill at 41WB437.

Figure 7: Presumed natural burn in TU6. level 3.........................................................22

Figure 8: Photograph of Feature 3 at $40 \mathrm{cmbs}$............................................................25

Figure 9: Plan view of Feature 3 at $40 \mathrm{cmbs}$..................................................................26

Figure 10: Plan view of Feature 5 at $60 \mathrm{cmbs}$..............................................................27

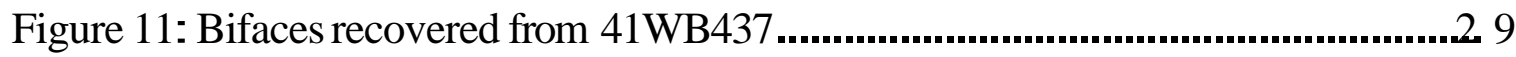

Figure 12: Sandstone abrader (a) and quartzite hammerstone (b) recovered from the surface of 41WB438 ..................................................................................... 3

Figure 13: Manos and mano fragments recovered from the surface of 41WB438.........35

Figure 14: Bifacial and unifacial tools and tool preforms recovered from the surface of 41W B 438

\section{LIST OF TABLES}

Table 1: List of excavation units and associated cultural features .................................. 17

Table 2: Artifact recovery by test pit and level. 41WB437 .........................................23

Table 3: Artifact recovery by test pit and level. 41WB438 ............................................. 32 


\section{INTRODUCTION}

In May,1996, plans were submitted by the Laredo District to the Environmental Affairs Division of the Texas Department of Transportation (TxDOT) to expand a 2.9 mile segment of U.S. Highway 83 south of Laredo, Texas, from two to four lanes. Although no new right-of-way is involved, an archeological survey of the affected part of the existing right-of-way was conducted by Jerry Henderson of the Environmental Affairs Division between August 20 and August 23, 1996. This survey resulted in the identification of four prehistoric archeological sites designated 41WB435, 41WB436, 41WB437, and 41WB438. Due to a lack of intact deposits, sites 41WB435 and 41WB436 were judged to be ineligible for listing on National Register of Historic Places. Although sites 41WB437 and 41WB438 were thought to subsume deep deposits with the potential to contain stratified archeological materials, their extent and eligibility for the National Register was unclear, and they were recommended for significance testing. The Department of Antiquities Protection, Texas Historical Commission, indicated concurrence with these findings in a letter dated 29 January, 1997.

The eligibility of sites 41WB437 and 41WB438 was investigated by personnel from the Environmental Affairs Division at TxDOT. Testing was begun on March 18, 1997, and continued intermittently through March 28, 1997, with a total of approximately 360 person-hours spent in the field. Testing was conducted through mechanical trenching and hand excavation of $1 \times 1$ test units. Four trenches and seven hand units were excavated within the boundary of 41WB437, and four trenches and two hand units were excavated on 41WB438. Testing was designed to determine whether stratified archeological components with the integrity and data content necessary to make a contribution to the archeological record of south Texas were present.

Sites 41WB437 and 41WB438 are situated on the north and south terraces, respectively, of San Idelfonso Creek at the point where the stream is crossed by U.S. Highway 83 (Figure 1). This location is approximately $7.5 \mathrm{~km}$ south of Laredo, Texas, and $0.6 \mathrm{~km}$ upstream from the confluence of San Idelfonso Creek and the Rio Grande River. The elevation of the two sites is approximately 114-119 m (375-390 feet) above mean sea level. Both alluvial terraces are heavily modified at the surface by a variety of cultural and natural processes, including extensive blading and pushing of the surface horizon; construction of an old, elevated road grade; excavation of a flanking ditch that probably provided fill for the road grade; local emplacement of up to $50 \mathrm{~cm}$ of spoil; emplacement of gravelly sediment for improvement of an unpaved access road and bank stabilization; extensive sheet erosion; and headward-cutting gully erosion. This disturbance has either buried or destroyed the context of the surface within about 20-25 $\mathrm{m}$ of the road, while obvious impacts in the distal parts of the right-of-way are more localized but still extensive. 


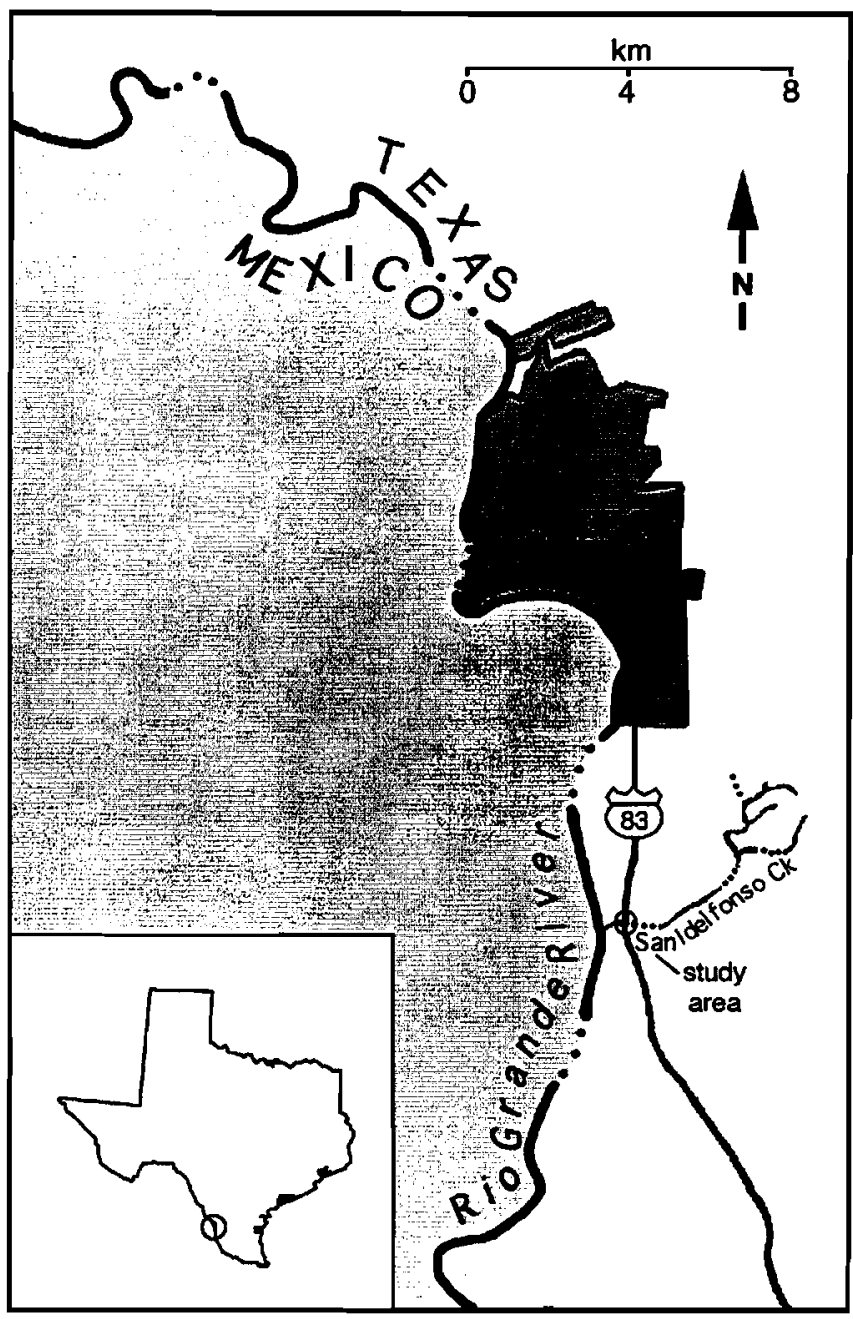

Figure 1: General location of $41 \mathrm{WB} 437$ and 41 WB438.

Examination of the two sites, both on the surface and through subsurface testing, suggested that the sites occupied the entirety of the two paired terrace landforms, and the site boundaries were set coincident with the boundaries of those landforms. Because the degree of surface disturbance was so pronounced, particularly on 41WB438, testing focused on determining whether intact archeological strata were preserved at depth in the terrace fill. This document describes the results of this testing, and presents determinations and recommendations based on those results. 


\section{ENVIRONMENTAL BACKGROUND}

\subsection{Climate and Hydrology}

The climate of the Laredo area is semi-arid subtropical. The region is characterized by predominantly megathermal, neotropical temperatures interrupted occasionally by mild freezes (Norwine 1995). Average daily high temperatures at Laredo vary from $67.2^{\circ} \mathrm{F}\left(22^{\circ} \mathrm{C}\right)$ in January to $98.2^{\circ} \mathrm{F}\left(41^{\circ} \mathrm{C}\right)$ in July, but the maximum daily temperature occurring during the coldest months will exceed $89^{\circ} \mathrm{F}$ in at least two years in ten, while maximum monthly temperatures in summer will exceed 103$106^{\circ} \mathrm{F}$ with the same regularity. Precipitation averages 19.8 inches $(500 \mathrm{~mm})$ per year, but is highly variable on a year-to-year basis. In fact, one of the hallmarks of the south Texas climate is extreme precipitation variability, which is much greater than typical for most semi-arid climates (Norwine 1995). Most precipitation occurs in relatively brief, intense thunderstorms that can generate significant runoff. San Idelfonso Creek is an ephemeral stream that drains an area of approximately $25 \mathrm{~km} 2$ upstream of the highway crossing, and is capable of generating strong flows in association with infrequent storms. However, such flows are quite rare, and the active channel at the site is vegetated with a variety of annual grasses and forbs.

\subsection{Physiography and Geology}

The study area is situated in the West Gulf Coastal Plain section of the Coastal Plains physiographic province (Fenneman 1938) less than a kilometer east of the incised valley of the Rio Grande River. The uplands surrounding the study area are developed on bedded sandstones and clays of the Eocene Laredo Formation (Barnes 1976) and capped by a thin lag of diverse fluvial gravels deposited by the ancestral Rio Grande River. The San Idelfonso Creek valley is relatively narrow $(300-500 \mathrm{~m}$ ), and is incised 8-12 m below the surrounding uplands. The terraces at the locality are both situated at roughly the same elevation (117.5-118.5 $\mathrm{m}$ above sea level), approximately 5-6 $\mathrm{m}$ above the heavily vegetated channel, and are designated the $T 1$ surface. The northern terrace is separated fiom the upland by a deeply incised, arcuate arroyo that flows along the terrace/upland contact to the west of the site. Aerial photographs of the project area indicate that this arroyo is a former channel of San Idelfonso Creek (Figure 2), and that the two terraces were once a single point bar on the south side of the stream. There are two possible causes for the relocation of the channel to its present position. The first possibility is that the channel was blocked by a low-gradient alluvial fan which enters the valley from a south-flowing tributary a short distance upstream (Figure 3; see also Figure 2), causing an avulsion that incised a new channel across the point bar and created the two terraces. However, it is more likely that the channel was intentionally relocated during construction of the U.S. Highway 83 bridge. Much of the north approach to the bridge occupies a former channel position, and relocating this oblique channel trace to a perpendicular with the road would have shortened the necessary bridge span considerably (see Figure 3). In either case, the channel was in its current configuration by 1959, when the earliest available aerial photographs were taken. 




Figure 2: Geomorphic sketch map of the vicinity of 41 WB 437 and 41 WB 438 prepared from aerial stereopair photographs. Areas outside the highway right-of-way were not examined except by peering over the fence, and the site boundaries are therefore approximate.

Both terraces are relatively level, but there is a distinct swale 1-1.5 m deep on the northern terrace within the boundary of 41WB437, and each exhibits some erosional beveling at the margin overlooking the channel. There is a low, narrow bench-like surface (TO) on the south side of the channel approximately 1-3 $\mathrm{m}$ above the stream that may represent a modern fill, but this surface has been so heavily modified during the modern era that little intact alluvium remains, and the surface was not investigated.

\section{Soils}

The soil in the San Idelfonso valley at the U.S. 83 crossing is mapped as Tela silty clay loam, while the mounding slopes and uplands are mapped as the Verick series, Copita series, and the Nido/rock outcrop series (Sanders and Gabriel 1985). Tela soils are Mollisols (Typic Argiustolls), Copita and Verick soils are Aridisols (Ustollic Calciorthids and Ustollic Haplargids, respectively), and Nido soils are Entisols (Ustic Torriorthents). 

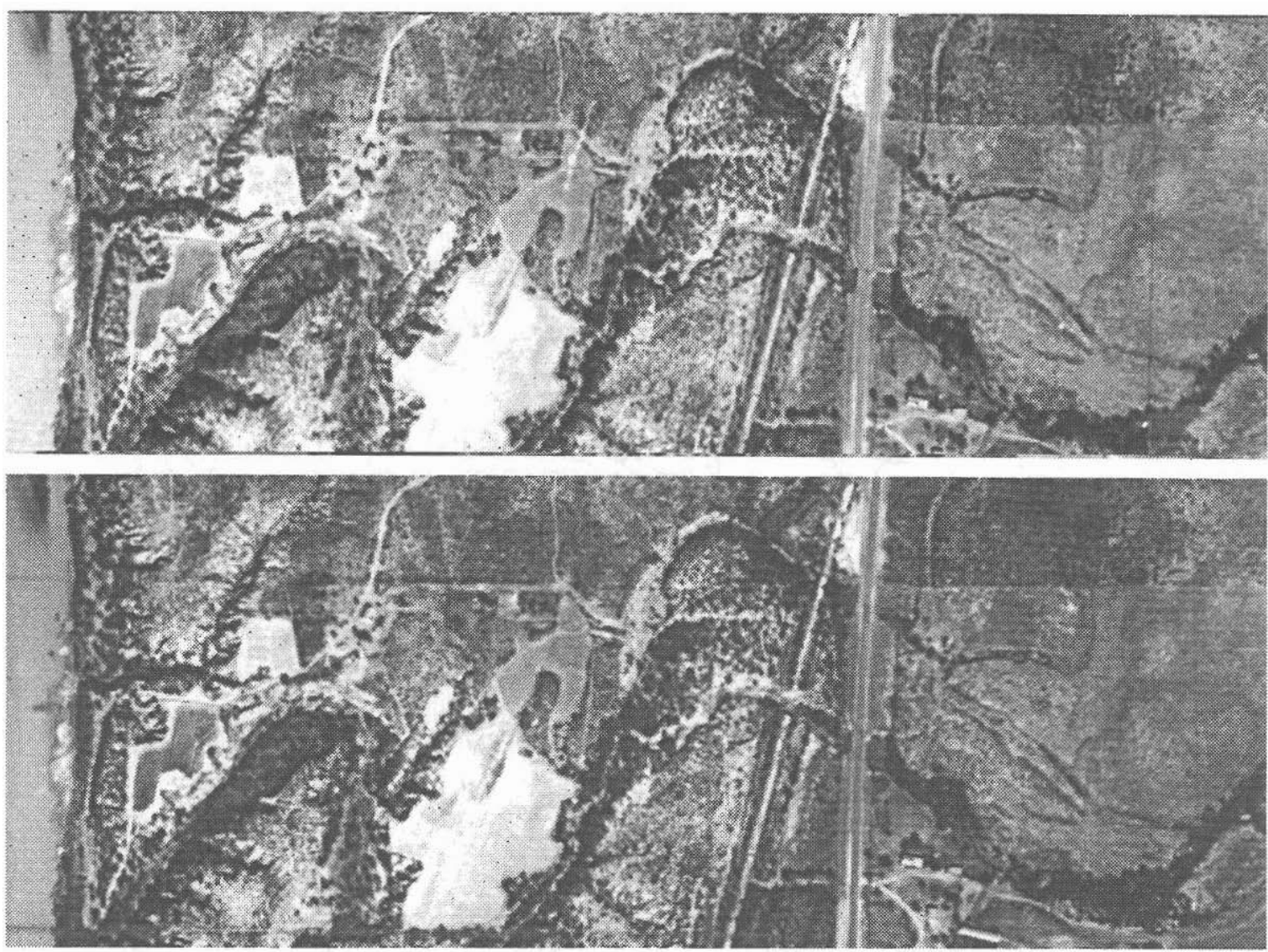

Figure 3: Stereopairimage of the U.S. 83 crossing at San Idelfonso Creek taken in 1959. Note the characteristic planifom morphology of the point bar and the old road trending SSW across the sites. The modern alignment of U. S.83 is situated about $\mathbf{1 0} \mathrm{m}$ west of the road in this photograph, which still exists as a highway frontage road.

Downstream a few hundred meters, the valley opens up into a broad expanse of Rio Grande River terrace, which is mapped as the Lagloriasilt loam. Lagloria soils are Inceptisols (Fluventic Ustochrepts). Tela soils are developed inrelatively clayey alluviumintributary valleys, and are typified by an A-Bt1-Bt2-BCk-Ck profile. Verick soils and Copita soils are developed on older alluvium or colluvium on the slopes, and exhibitrelatively strong profiles with argillic horizons and stage II calcic horizons, respectively. The upland is characterized by bare patches of sandstone and lag gravel interspersed with the thin, weak soils of the Nido series.

\subsection{Biota}

The Laredo area is within the western Tarnaulipan biotic province of Blair (1950). Overall, the Tamaulipan province is characterized by a preponderance of thorny brush such as mesquite, acacia, huisache, prickly pear, and tasajillo. Vegetation on the sites consists of a mixture of species typical of moister "riparian" settings such as relatively large mesquite, huisache, bunch grasses, and a variety of weedy annuals. Identified taxa include lotebush, huisache, guayacan, retama, King Ranch bluestem, buffelgrass, and bermuda grass. Ground visibility varies from less than $20 \%$ to more than 
$80 \%$, with the highest visibility characteristic of areas undergoing active erosional beveling.

A variety of fauna is typical of the Tamaulipan province, although many taxa have been extirpated during the historic period. Blair (1950) notes the occurrence of at least 61 species of mammals and 79 species of reptiles and amphibians in the province. The number of birds is not noted by Blair, but it is in excess of 100 species. Although all exploitable species were probably preyed upon by man at one time or another, taxa of particular economic importance include white-tailed deer, pronghorn, bison, cottontail and jack rabbit, and turkey. 


\section{ARCHEOLOGICAL BACKGROUND}

The archeological record in South Texas and adjacent portions of northern Mexico spans at least 11,500 years, yet remains poorly known. Most recorded sites in the region are surficial or highly erosional, and tightly constrained, isolated components are rare. In broad terms, the cultural chronology of South Texas can be broken up into four periods: Paleoindian, Archaic, Late Prehistoric, and Protohistoric/Historic. Although the specific traits and temporal boundaries of these periods differ from place to place, this very generalized classification is equally applicable to most of western North America, and is thus not particularly informative. Nevertheless, it remains the most commonly applied organizational system for the archeological record, and is used to frame this brief discussion. Several more detailed and comprehensive overviews of South Texas prehistory exist; the interested reader is referred in particular to two summaries by T. R. Hester (1980; 1995).

The Paleoindian Period spans the latest Pleistocene and early Holocene (roughly 11,500 through $8,500 \mathrm{BP}$ ), and can be subdivided into an earlier phase, characterized by fluted projectile points of the Clovis and Folsom lithic traditions, and a later phase, characterized by a diverse suite of finely made but unfluted point styles (e.g, Angostura, Golondrina, Scottsbluff, Plainview, St. Mary's Hall). The Paleoindian Period is unique in that many of the same stylistic traditions were present over immense areas of North America at more or less the same time. Paleoindian peoples were clearly engaged in big game hunting, with the earlier traditions exploiting large Pleistocene fauna that are now extinct (e.g., Mammuthus columbi, Bison antiquus, Bison occidentalis ) and the later traditions exploiting modem fauna. While earlier interpretations tended to view Paleoindians as specialized big game hunters (e.g., Wormington 1957), the prevailing opinion is clearly shifting towards viewing Paleoindians as people who practiced broadbased hunting and gathering, with hunting of big game forming only one aspect of the economy (e.g., Collins 1995).

In this light, the shift from the Paleoindian Period to the Archaic Period can be seen as an evolutionary, rather than revolutionary, process that occurred as the late Pleistocene environment gave way to biota adapted to warmer, more arid conditions. In general, the Archaic was characterized by a proliferation of projectile point styles and a continuation of (rather than a shift to, as previously believed) broad based, mobile hunting and gathering. While the timing of transitions is far from firmly established, the Archaic is commonly divided into the Early Archaic subperiod (roughly 8,500 to 4,500 BP), Middle Archaic subperiod (roughly 4,500-2,500 BP) and Late Archaic subperiod (roughly 2,500 to 1,400 BP). Hester (1989; 1995) recognizes two broad lithic traditions in the Early Archaic of South Texas: an "Early Corner Notched" horizon, followed by an "Early Side Notched" horizon. The "Early Corner Notched" is characterized by projectile points like Martindale, Uvalde, Bandy, and Baker and the thick, beveled biface termed the Guadalupe Biface. The "Early Basal Notched" is characterized by projectile points with deep basal notches like Andice and Bell and relatively large Clear Fork gouges. The distinctive, unstemmed triangular South Texas points like Abasolo and 
Tortugas may have also appeared during the latter Early Archaic. As Hester (1995) notes, little specific information is known about Early Archaic subsistence and settlement patterns in south Texas. However, it appears that Early Archaic peoples were highly mobile and exploited a wide range of biotic resources.

While Early Archaic projectile point styles are predominantly related to adjacent areas like the Edwards Plateau and lower Pecos, Middle Archaic marks the florescence of a lithic tradition that is focused on south Texas and adjacent parts of northern Mexico. This tradition, which was characterized by unstemmed triangular and leaf-shaped points termed Tortugas, Kinney, and Abasolo and distally beveled Dimmit and Nueces tools. Stemmed points and lithic tools that also occur outside of South Texas (e.g., Pedernales, Morhiss, Lange, Langtry, Clear Fork gouge) are also common. As in central Texas, the Middle Archaic in south Texas witnessed an increase in the frequency of burned rock features that many researchers (e.g., Hall et al. 1986; Collins 1995; Black, Ellis et al.1997) attribute to plant processing. Middle Archaic sites are typically open campsites, and were usually situated in lowland settings adjacent to water. However, many upland lithic procurement localities are also present throughout south Texas, particularly in association with the high stream cobble lags known as the Uvalde Gravel. While these exposed sites are very difficult to date, they almost certainly have a Middle Archaic component.

The Late Archaic in South Texas is characterized by a variety of stemmed projectile point forms that also occur in surrounding regions (e.g., Marcos, Montell, Ensor) and use of unstemmed points (e.g., Catan, Matamoros, Desmuke) that are similar to, but smaller than, the earlier triangular and leaf-shaped points like Abasolo and Tortugas. Large, finely made triangular bifaces are also common, as are small, steepedged triangular bifaces termed Olmos tools. As in the preceding period, subsistence continued to be broad-based, focusing on a wide variety of small animals, aquatic resources like shellfish, and plant foods. Ground stone implements (manos, metates) are often associated with Late Archaic sites, indicating plant processing, and burned rock features remain common. Hester (1995) notes that Late Archaic sites are typically associated with stream courses, although lithic procurement and other upland sites surely also occur.

The transition to the Late Prehistoric period is principally a technological change in South Texas. While the introduction of the bow and arrow and ceramic technology was accompanied by shifts to horticulture and increased sedentism in areas to the west (e.g., the Anasazi) and east (e.g., the Caddo), in South Texas these innovations do not seem to have altered the basic mechanics of making a living, which remained broadbased hunting and gathering. There is no evidence that horticulture, even in a rudimentary form, was ever practiced in the Laredo area before the Spanish incursion. However, there is clear evidence of contact and occasional trade between people in South Texas and more sedentary peoples, including the Caddo in East Texas and Mesoamerican groups from Central Mexico. The earlier part of the Late Prehistoric is marked by the introduction of arrowpoints (e.g., Scallorn, Edwards) and related items like shaft 
straighteners. Unstemmed arrow points (e.g., Young, Zavala, Fresno), some of which are quite crudely made, are also common. Ceramics appear in relatively small numbers somewhat later, and don't become common until the Protohistoric period. One notable shift in the latter Late Prehistoric is the appearance of the distinctive toolkit of the Toyah Focus, which also occurs throughout central, west-central, and north-central Texas. This phenomenon is frequently interpreted as the probable result of trait diffusion (Black 1989; Hester 1995), although Johnson (1994) argues that it probably represents an incursion of new people. The Protohistoric/Historic period marks the incursion of the Spanish, the founding of the mission system, and the relatively abrupt end of a way of life that had existed for millennia.

Overall, the archeological record of the Laredo area remains relatively little known, largely because so little work has been done in the region. Extant reports fiom the region include McGraw 1983, Bement and Rowan 1988, Ellis and Dodt-Ellis 1988, Davis 1992; Wormser and Clark 1992; Kibler 1996; and Maslyk et al. 1997. Two other reports are in preparation in connection with the Columbia Solidarity International Bridge upstream from Laredo. The report on investigation of the bridge site is in draft form (McGraw and Thompson n.d.), and investigation of sites identified along the Camino Colombia toll road to the bridge (Davis 1992) is in early stages of analysis and reporting by SWCA Associates. These reports document that archeological sites in the area tend to be situated in erosional settings with poor potential for contextual integrity, although some deep, stratified sites have been addressed (McGraw 1983; Maslyk et al. 1997). Significantly, all extant investigations consist of limited survey and testing programs. As Hester (1995) points out, no systematic excavation of a stratified site has yet been conducted in the area. 


\section{METHODS}

Four trenches were excavated on each site to examine terrace stratigraphy and prospect for deeply buried cultural material. Trenching was performed with an excavator, which is a trackhoe with a smooth-bladed bucket that can be canted fiom the horizontal. On 41WB437, BT1 and BT4 were excavated to depths of $330 \mathrm{~cm}$ and $290 \mathrm{~cm}$, respectively, to examine deep stratigraphy of the site. BT 2 was discontinued at a depth of approximately $30 \mathrm{~cm}$ when a shallowly buried burned rock feature was encountered, and BT 3 was excavated to a depth of $106 \mathrm{~cm}$ to examine near-surface deposits in greater detail. On 41WB438, four trenches were excavated to depths of between 140 and 290 $\mathrm{cm}$, penetrating well into the culturally sterile deposits of Unit 1 . With the exception of BT2 on 41WB437, all trenches were examined and described using standard soil terminology (Olsen 1976). Sampling was limited to charcoal fiom cultural features to provide temporal control for the depositional sequence at 41WB437. No samples were collected fiom $41 \mathrm{WB} 438$.

Trenching was supplemented by hand-excavated units. The majority of these units were $1 \times 1 \mathrm{~m}$ in size, but one $50 \times 50 \mathrm{~cm}$ unit was excavated on 41WB437. Two 1 x $1 \mathrm{~m}$ units were excavated on 41WB438, and $61 \mathrm{x} 1 \mathrm{~m}$ units and $150 \mathrm{x} 50 \mathrm{~cm}$ unit were excavated on 41WB437 (Table 1). All units were randomly oriented, but a detailed map of the layout of trenches and test units was prepared using a total data station (Figure 4). Hand excavation was accomplished with shovel and trowel. All sediment was screened through 1/4" hardware cloth. Artifacts (exclusive of burned rock) were bagged and returned to the laboratory, where they were washed, categorized, and cataloged. Charcoal samples were collected with sediment matrix and picked in the laboratory to obtain samples for radiometric dating.

The six units excavated on 41WB437 formed two small contiguous block excavations. TU 1-4 were excavated on the margin of BT 2 to investigate Feature 3, which was initially exposed by the backhoe. All four units were necessary to fully expose the rock concentration. Similarly, three contiguous units (TU 5-7) were necessary to expose the feature (Feature 5) found in TU5, a randomly placed unit placed after trenching had been completed. 
Figure 4: Location of test units, backhoe trenches, and physical features on 41W B 437 and 41W B38. Test unit and backhoe trench locations, and the bridge, highway, and R-0-W fencelines are precisely located with a total data station. Other physical features are based on sketch mapping and are approximate.

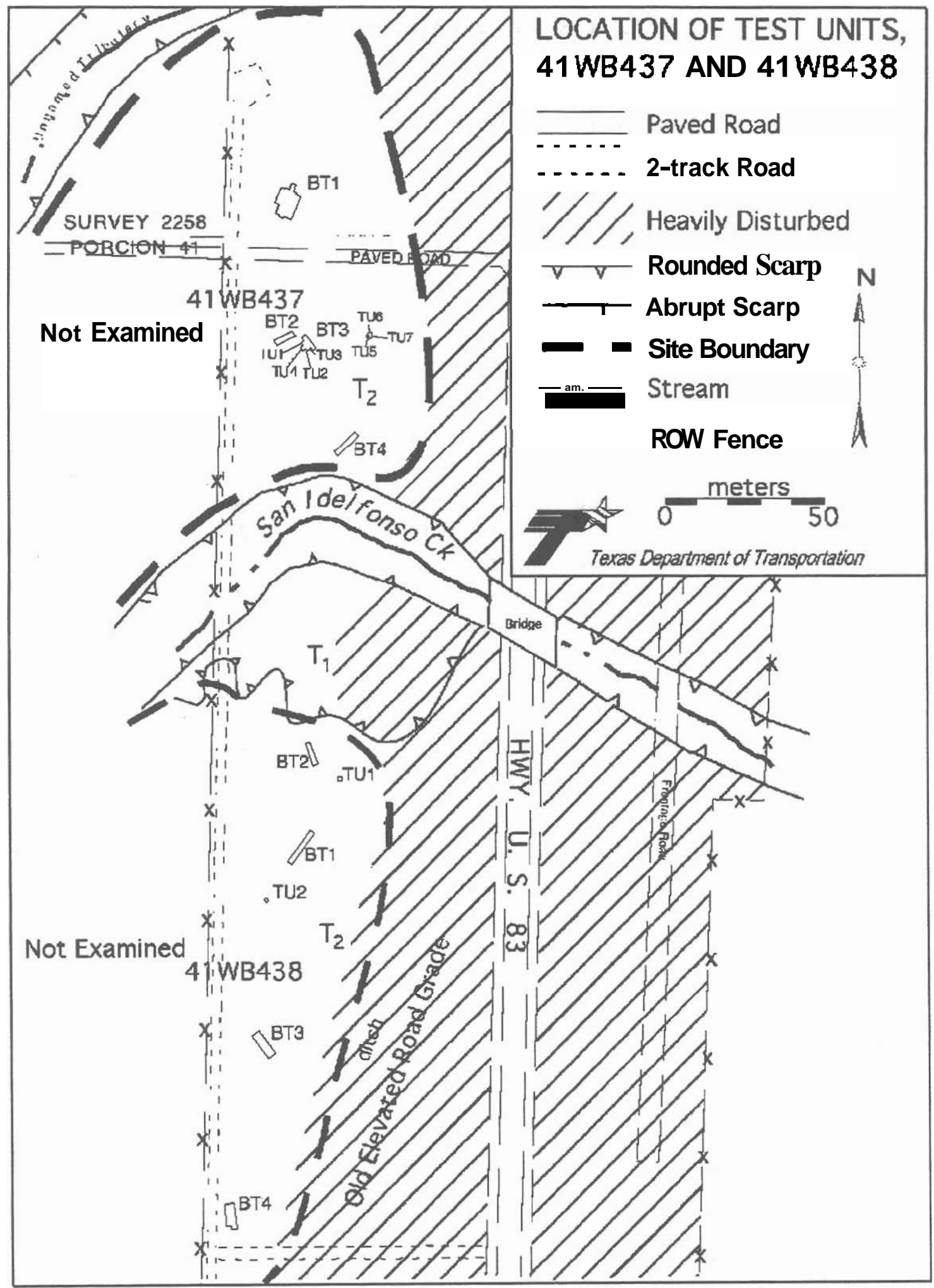


Table 1: List of excavation units and associated cultural features.

\begin{tabular}{|c|c|c|c|c|c|c|}
\hline Site & $\overline{\mathrm{TU}}$ & $\mathbf{B T}$ & Size (m) & Depth $(\mathrm{cm})$ & Feature & Comments \\
\hline \multirow[t]{9}{*}{ 41WB437 } & I & - & $1 \times 1$ & 040 & 3 & Adjacent to BT2 \\
\hline & 2 & - & $1 \times 1$ & 040 & 3,4 & Adjacent to $B T 2$ \\
\hline & 3 & - & $1 \times 1$ & 040 & 3 & Adjacent to $B T 2$ \\
\hline & 4 & - & $1 \times 1$ & 040 & 3 & Adjacent toST2 \\
\hline & 5 & - & $1 \times 1$ & 060 & 5 & \\
\hline & 6 & - & $1 \times 1$ & 060 & 5 & \\
\hline & 7 & - & $0.5 \times 0.5$ & 060 & 5 & \\
\hline & - & 1 & $10.2 \times 6.1$ & $0-330$ & 1.6 & $\begin{array}{c}\text { sparse bumed sandstone } \\
\text { throughout; Feature } 1 \text { at } 180 \mathrm{~cm} \text {; } \\
\text { Feature } 6 \text { at } 80 \mathrm{~cm} \text { (noted in wall } \\
\text { after excavation) } \\
\text { trench halted to investigate and } \\
\text { record Feature } 3(25 \mathrm{~cm})\end{array}$ \\
\hline & - & 3 & $6.3 \times 1.3$ & $0-106$ & 2 & $\begin{array}{c}\text { sparse bumed sandstone feature } \\
\text { (Feature } 2 \text { ) at } 25 \mathrm{~cm} \text { bgs briefly } \\
\text { recorded, exhumed with } \\
\text { machine:Feature } 7 \text { noted in east } \\
\text { wall after excavation } \\
\text { no significantcultural material } \\
\text { noted }\end{array}$ \\
\hline \multirow[t]{6}{*}{ 41WB438 } & 1 & - & $1 \times 1$ & $0-60$ & - & sparse cultural material \\
\hline & 2 & - & $1 \times 1$ & $0-50$ & - & sparse cultural material \\
\hline & - & 1 & $11.6 \times 1.3$ & $0-290$ & - & \\
\hline & - & 2 & $6.7 \times 1.3$ & 0135 & - & \\
\hline & - & 3 & $7.9 \times 26$ & $0-190$ & - & \\
\hline & $=$ & 4 & $7.4 \times 2.7$ & 0-195 & - & \\
\hline
\end{tabular}




\section{RESULTS OF INVESTIGATIONS}

\subsection{Stratigraphy}

Two principal allostratigraphic units were identified in the trenches excavated on 41WB437 and 41WB438. Unit 1 is limited to the south side of San Ildefonso Creek beneath 41WB438. This unit forms the core of the southern terrace and consists of massive, brownish yellow (10Y R 6/6) to light olive brown (2.5YR 5/6) loamy sands and sandy loams. It contains a relatively well-developed stage II calcic horizon characterized by white, hard, chalky carbonate nodules between 0.25 and $0.5 \mathrm{~cm}$ in diameter. These nodules occupy less than $2 \%$ of the volume of the upper fill, and decrease in density with depth. Although the internodular matrix is still quite reactive with dilute $\mathrm{HCl}$, the reaction is noticeably less vigorous than the reaction of sediments in the overlying unit, suggesting that the internodular matrix may be slightly leached. No remnant of an associated A horizon was observed. This fact, coupled with the presence in the upper part of the preserved fill, indicates that the fill was truncated by surface scour, then buried by renewed aggradation at some later point. The total thickness of the fill is unknown, but the trenches indicate that it has a thickness of at least $2.5 \mathrm{~m}$.

Unit 2 consists of silty to silty loam sediments that range from dark brown and brown $(10 Y \mathrm{R} 3 / 3-4 / 3)$ in the A horizon to brown, pale brown, very pale brown, yellowish brown, and light yellowish brown (10YR 5/3-5/4; -6/3-6/4; -7/3) in the B and $\mathrm{C}$ horizons. In terms of texture and of degree of soil development, the sediments on site are much more similar to the La Gloria series typical of the Rio Grande terraces than to typical Tela soils, which are mapped at the locality by the Soil Conservation Service (Sanders and Gabriel 1985). Nevertheless, the geometry and texture of the fill suggests that it was probably formed by sediments carried by San Idelfonso Creek rather than by backflooding of the valley by the Rio Grande.

Unit 2 occurs as a relatively thin (up to approximately $1 \mathrm{~m}$ ) drape on the southern terrace (41WB438), but forms the thick core of the northern terrace (41WB437) (Figure 1). The texture of the unit varies from silty loam to almost pure silt. In several trenches, including BT1 and BT3 on 41WB437 and BT2-4 on 41WB438, the sediments are clearly stratified, with somewhat structured packets of silty loams alternating with massive silts, while in other trenches this stratification is less apparent. Maximum observed thickness of the unit was $3.3 \mathrm{~m}$ in BT 1, 41WB437.

Typically, the loamier strata in Unit 2 exhibit a relatively weak structure that is quite unusual. For want of a better term, this structure was referred to as subangular blocky in the trench descriptions (Appendix I), but it clearly does not conform to the typical meaning of the term. Although detailed micromorphological examination would be required to thoroughly understand the structure of these sediments, macroscopic visual inspection suggests that it represents the cumulative effect of desiccation, faunal and

floral turbation, and silt infiltration. The most recognizable element of the structure consists of small $(0.1-1.0 \mathrm{~cm})$, irregular, randomly-oriented blocks resulting from the 


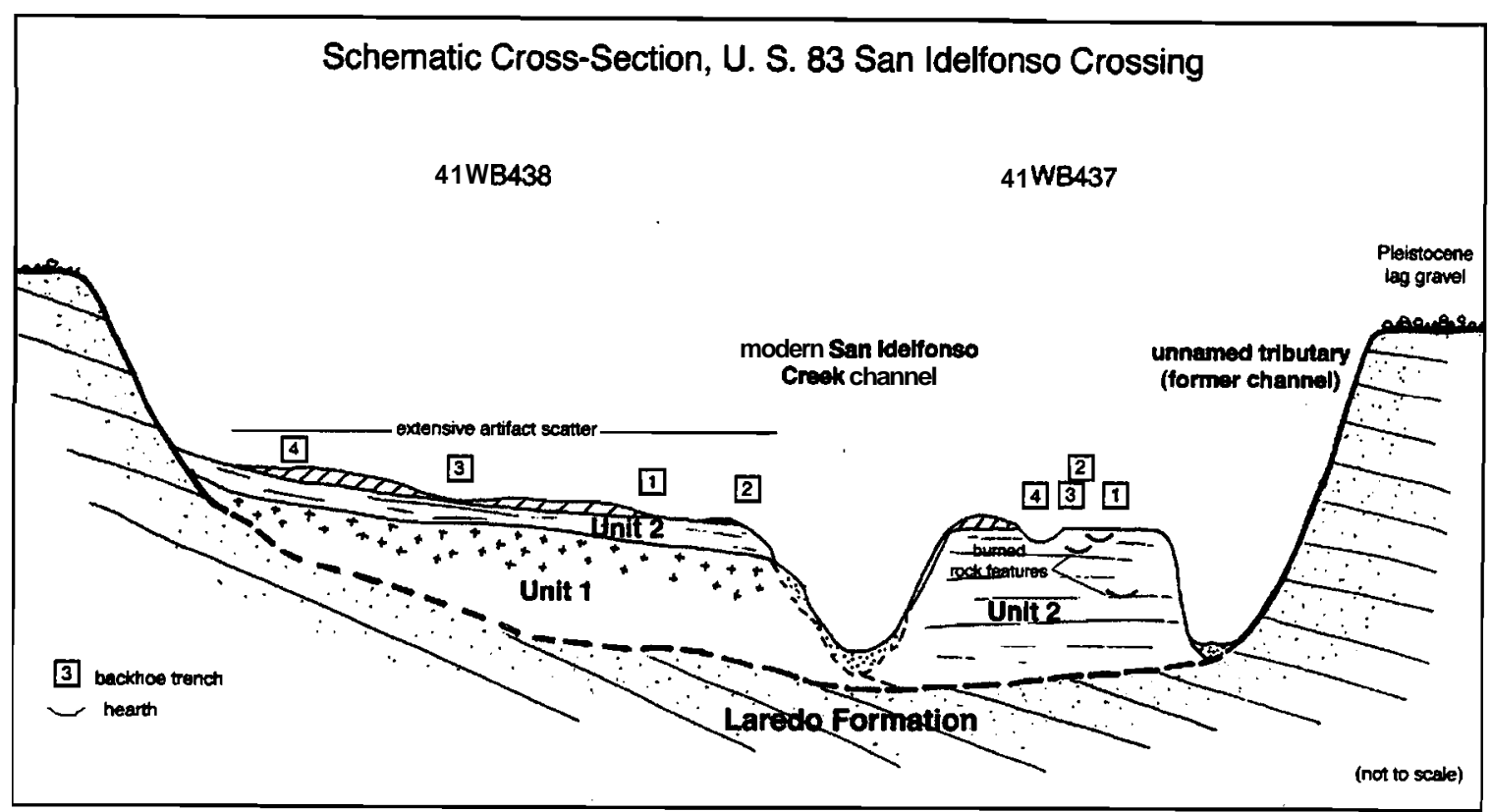

Figure 5: Schematic stratigraphic cross-section of the San Idelfonso valley at the location of 41 WB437 and 41 WB438.

desiccation cracking and subsequent disruption of thin flood drapes. Typically, these small peds are highly disrupted and cut with a dense network of turbation structures including insect krotovina, root traces, and occasional rodent-sized krotovina. Many of the interstices between the "peds" and vertical turbation tubules are coated with thin to moderately thick coats of illuvial silt. In one case (41WB438, BT3), there are at least three distinct packets of relatively well-preserved silty drapes, but in most cases these drapes appear to have been disrupted, providing a blocky structure that was overprinted by extensive burrowing and silt infiltration.

No cultural material was noted in association with Unit 1. Although the rate of carbonate morphology development in the Laredo area is not at all clear, the presence of a relatively strong stage II carbonate morphology probably indicates that the Unit I fill is at least early-middle Holocene in age, and more likely represents a late Pleistocene fill (Gile et al. 1966; Birkeland 1984). Although there is the potential for Unit 1 to contain cultural material, no such material was observed in any of the trenches.

Unit 2 represents the culture-bearing allostratigraphic unit present on both sites. However, cultural material is relatively sparse in the upper fill at 41WB438; particularly in comparison to the material scattered on the extant ground surface. This suggests that the surface was either relatively stable during most of the span of occupation, or that the relatively coarse lithics and burned rocks were concentrated as a lag as sheet erosion "deflated" the surface. Very few artifacts were noted in the trenches, although dispersed burned sandstone and a few isolated flakes and mussel shells were noted at depths of up to $50 \mathrm{~cm}$ below the pre-disturbance ground surface. 
On the northern side of the stream, the deposits of Unit 2 are much thicker (probably up to $4 \mathrm{~m}$ locally), and make up the entire body of the terrace. A trench was excavated into a prominent swale trending across the surface to determine if it was infilled with more recent, inset deposits. This proved not to be the case; the swale is clearly an erosional feature underlain by the same unit forming the remainder of the terrace, and is capped with only a few $\mathrm{cm}$ of relatively recent colluvial and wash deposits. The prominence of stratification caused by the alternation of relatively silty and loamy facies varies fiom trench to trench, but is generally more pronounced with distance fiom the modern channel (and thus, with proximity to what was probably the active channel at that time). In the only deep trench with appreciable amounts of cultural material, BT1 on 41WB437, the cultural material appears to be restricted almost exclusively to the loamier facies, suggesting that the massive, silty beds may represent individual large flood deposits while the loamy facies may represent more gradual aggradation of the point bar surface arising from many lower magnitude events. In addition to the three discrete burned rock and charcoal clusters examined, a number of isolated probable burned rocks are dispersed throughout Unit 2 to depths of at least $2 \mathrm{~m}$. These reddened or blackened sandstone clasts clearly represent material too large to have been lifted out of the channel and deposited on the former floodplain, and are almost certainly "manuports" that were deposited on the former surfaces by people. However, it is likely that many of these clasts were moved across the terrace--possibly for considerable distances-during flood events, and are therefore not in primary cultural context.

Charcoal samples collected from three burned rock features on $41 \mathrm{WB} 437$ were submitted for radiocarbon assay to determine the timing of Unit 2 aggradation and the age of the interbedded cultural material. The stratigraphically highest of these samples was obtained fiom Level 4 in Feature $3(30-40 \mathrm{cmbs})$. It yielded a c13 corrected age of 2060 +/- 80BP (1 sigma calibrated $=175$ BC to AD 45). A second sample was obtained fiom Feature 6, a concentration of burned rock and charcoal exposed $80 \mathrm{cmbs}$ in the wall of BT 1. It yielded a corrected AMS radiocarbon age of $2130+/-40$ BP (1 sigma calibrated $=\mathrm{BC} 345$ to 310 and BC 210 to 40). Finally, a third charcoal sample was collected from Feature 1, which was exposed at a depth of $180-185 \mathrm{cmbs}$ in BT1. It yielded a corrected AMS radiocarbon age of 3240 +/- 50 BP (1 sigma calibrated = BC 1620 to 1410). Considered with the stratigraphic character of the remainder of the profile, these data suggest that Unit 2 aggraded between about 4,000-5,000 BP and 1,500-2,000 BP.

Figure 6 illustrates nominal rates of sedimentation derived fiom these three radiocarbon ages. The estimate for the average rate of sedimentation between $1.8 \mathrm{~m}$ and $0.8 \mathrm{~m}$ is $0.94 \mathrm{~cm} / \mathrm{yr}$, or approximately $1 \mathrm{~cm}$ every 10.6 years. Because both of these ages are from the same trench, this estimate is probably a highly accurate long-term average, although it is likely that the aggradation was punctuated (i.e., the massive silt strata accumulated rapidly during brief, high magnitude flood events and the structured silty loam strata accumulated in a more gradual manner as a result of more frequent, lower magnitude floods). Similar strata, which probably represent accumulation at roughly the 


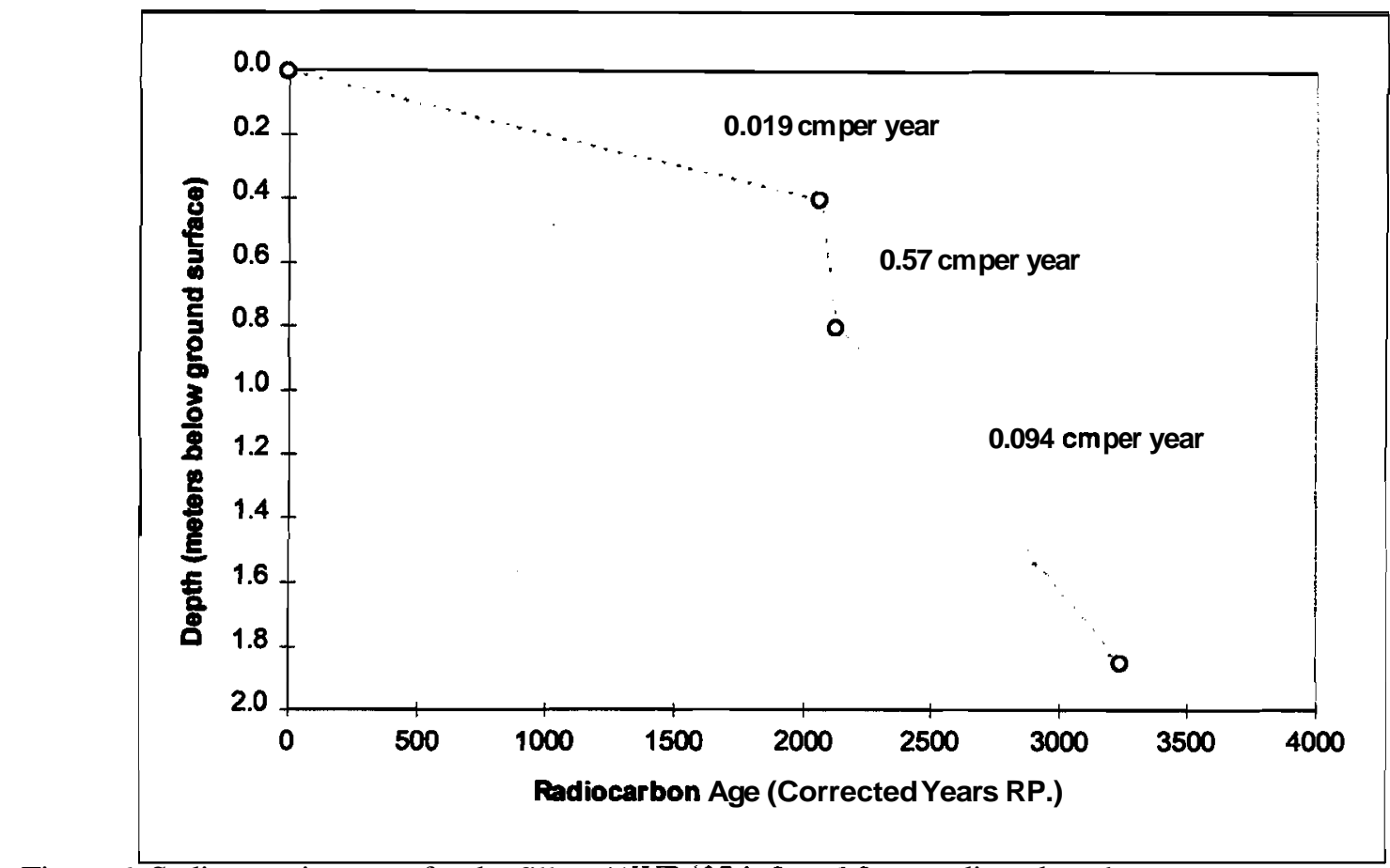

Figure 6: Sedimentation rates for the fill at 41WB437 inferred from radiocarbon data.

same long-term rate, extend to a depth of about $300 \mathrm{~cm}$, where they overlie thin channel deposits.

The estimate for the rate of sedimentation between $0.8 \mathrm{~m}$ and $0.4 \mathrm{~m}$ is markedly higher, $0.57 \mathrm{~cm} / \mathrm{yr}$, which equates to $1 \mathrm{~cm}$ every 1.75 years. However, because these two ages are from discrete trenches separated by about $25 \mathrm{~m}$, and because the deeper age is situated more distally on what was the actively aggrading point bar, it is likely that this rate of sedimentation is unrealistically high. Nevertheless, it does indicate that the rate of sedimentation was not dramatically slower in the upper meter of site deposits. Finally, the nominal rate of sedimentation of the upper $40 \mathrm{~cm}$ of the terrace is $0.019 \mathrm{~cm} / \mathrm{yr}$, or roughly $1 \mathrm{~cm}$ every 53 years. This is almost certainly unrealistic; it is likely that the upper $40 \mathrm{~cm}$ of fill aggraded in a fraction of that time, and then was abandoned by downcutting of the channel.

\subsection{Results of Testing at 41 WB 437}

\subsubsection{Test Unit Descriptions}

Seven formal test units, encompassing a total volume of $2.95 \mathrm{~m}^{3}$, were excavated on 41WB437. In addition, the remnants of Feature 1 were examined by limited, unstructured excavation on a bench in BT1. Test Units 1-4 represent a small block adjacent to BT2, and were excavated to expose and investigate a cluster of burned rock and charcoal observed in the trench. Each of these four units were excavated to a depth 
of $40 \mathrm{cmbs}$, exposing Feature 3, a large bumed rock hearth, and Feature 4, a small burned rock cluster situated stratigraphically above the largerfeature. Each of these units exposed the same sediments (Unit 2), which consisted of brown (10YR 4/3), massive sandy loam that became slightly siltierwith depth. Low frequenciesof artifacts (total $\mathrm{N}=60 ; 37.5 \mathrm{per}^{3}$ ) were recovered from the four units (Table 2). Slightly more than half of the 41 lithic artifacts are from level 2 , suggesting that they are associated with Feature 4. Only 5 lithic artifacts were recovered from Level 4, the basal elevation of Feature 3. However, fragmentary mussel shell and fine bone fragments were recovered from the feature, and all were concentratedin a single test unit (TU3).

A second small block was excavated east of TU 1-4 toinvestigate and expose a buried feature discovered in a randomly-placed test pit. This feature (Feature 5) was discovered in Level6 of TU5. TU6 and TU7 (the latter measuring $50 \mathrm{~cm} \times 50 \mathrm{~cm}$ ) were subsequently placed as contiguous units to fully expose the feature (seeFigure 4). All three of these units were excavated to a depth of $60 \mathrm{cmbs}$, and exposed a relatively featureless profile similar to the profile described for TU 1-4 above. The most extensive assemblage of flaked stone artifacts recovered from the site is associated with Levels 3 and 4 in Test Units 5, 6, and 7. These two levels represent avolume of $0.45 \mathrm{~m}^{3}$ from three adjacent units surrounding Feature 5 , and yielded 74 pieces of lithic debitage $\left(164\right.$ per $\left.^{3}\right)$. However, a number of bumed tree roots and a possible burned fence post fragment were also present in Levels 3 and 4 of TU6; these were interpreted in the field as the probable resultof a historic burn, and no feature designation was made, nor was any of the abundant charcoal was collected (Figure 7). Only a few flakes were associated with Feature 5, which lay 50-60 cmbs.

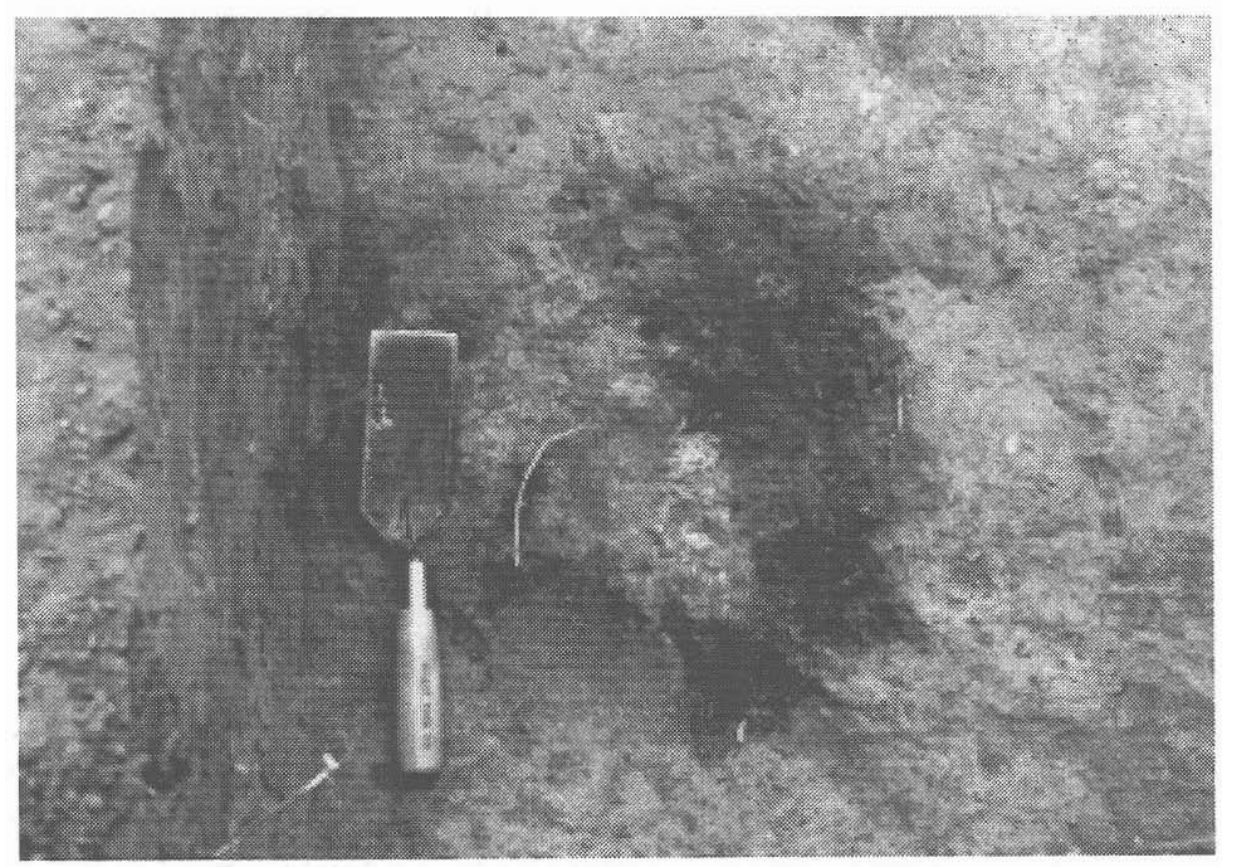

Figure 7: Presumed natural bum in TU6, level3. 
Finally, an informal, unnumbered hand unit measuring roughly $110 \mathrm{~cm} \times 190 \mathrm{~cm}$ was excavated on a bench in BT 1 to expose the remaining part of Feature 1, which was bisected by the backhoe. The results of this brief test are described below, in the discussion of Feature 1.

Table 2: Artifact recovery by test pit and level, 41 WB437

\begin{tabular}{|c|c|c|c|c|c|c|c|c|c|c|}
\hline Unit & Level & $\begin{array}{l}\text { Formal } \\
\text { Littic } \\
\text { Tools }\end{array}$ & $\begin{array}{c}\text { Cores and } \\
\text { Earty-Stage } \\
\text { Bifaces }\end{array}$ & $\begin{array}{l}\text { Expedient } \\
\text { Lithic } \\
\text { Tools }\end{array}$ & Flakes & $\begin{array}{l}\text { Chips } \\
\text { and } \\
\text { shatter }\end{array}$ & $\begin{array}{l}\text { Ground } \\
\text { Stone }\end{array}$ & $\begin{array}{l}\text { bone } \\
\text { and } \\
\text { shell }\end{array}$ & $\begin{array}{l}\text { historic } \\
\text { artifacts }\end{array}$ & $\begin{array}{c}\text { Totals by } \\
\text { Level }\end{array}$ \\
\hline \multirow[t]{4}{*}{ TU1 } & 1 & 0 & 0 & 0 & 0 & 3 & 0 & 0 & 0 & 3 \\
\hline & 2 & 0 & 0 & 0 & 1 & 5 & 0 & 1 & 1 & 8 \\
\hline & 3 & 0 & 1 & 0 & 0 & 0 & 0 & 0 & 0 & 1 \\
\hline & 4 & 0 & 0 & 0 & 3 & 0 & 0 & 0 & 0 & 3 \\
\hline \multicolumn{2}{|c|}{ Totals by Class } & $\overline{0}$ & 1 & 0 & 4 & 8 & 0 & 1 & $\overline{1}$ & 15 \\
\hline
\end{tabular}

\begin{tabular}{|c|c|c|c|c|c|c|c|c|c|c|}
\hline \multirow[t]{4}{*}{ TU2 } & 1 & 0 & 0 & 0 & 1 & 1 & $\overline{0}$ & 0 & 0 & 2 \\
\hline & 2 & 0 & 0 & 0 & 2 & 3 & 0 & 0 & 0 & 5 \\
\hline & 3 & 0 & 0 & 0 & 0 & 3 & 0 & 0 & 0 & 3 \\
\hline & 4 & 0 & 0 & 0 & 1 & 0 & 0 & 0 & 0 & 1 \\
\hline \multicolumn{2}{|c|}{ Totals by Class } & 0 & 0 & 0 & 4 & 7 & $\overline{0}$ & 0 & 0 & 11 \\
\hline
\end{tabular}

\begin{tabular}{|l|c|c|c|c|c|c|c|c|c|c|}
\hline TU3 & 1 & 0 & 0 & 0 & 1 & 1 & 0 & 1 & 1 & 4 \\
& 2 & 0 & 0 & 0 & 1 & 5 & 0 & 0 & 0 & 6 \\
& 3 & 1 & 0 & 0 & 2 & 1 & 0 & 0 & 0 & 4 \\
& 4 & 0 & 0 & 0 & 1 & 0 & 0 & 15 & 0 & 16 \\
\hline
\end{tabular}

\begin{tabular}{|l|l|l|l|l|l|l|l|l|l|l|}
\hline TU4 & 1 & 0 & 0 & 0 & 0 & 0 & 0 & 0 & 0 & 0 \\
& 2 & 0 & 0 & 0 & 4 & 0 & 0 & 0 & 0 & 4 \\
& 3 & 0 & 0 & 0 & 0 & 1 & 0 & 0 & 0 & 1 \\
& 4 & 0 & 0 & 0 & 0 & 0 & 0 & 0 & 0 & 0 \\
\hline
\end{tabular}

\begin{tabular}{|l|c|c|c|c|c|c|c|c|c|c|}
\hline TU5 & 1 & 0 & 0 & 0 & 1 & 2 & 0 & 0 & 0 & 3 \\
\cline { 2 - 11 } & 2 & 0 & 0 & 0 & 1 & 3 & 0 & 0 & 0 & 4 \\
19 & 15 \\
& 3 & 0 & 0 & 0 & 17 & 2 & 0 & 0 & 0 & 3 \\
\hline 4 & 0 & 0 & 0 & 4 & 9 & 0 & 2 & 0 & 2 \\
\hline 5 & 0 & 0 & 0 & 0 & 3 & 0 & 0 & 0 & 46 \\
\hline
\end{tabular}


Table 2 (Continued)

\begin{tabular}{|c|c|c|c|c|c|c|c|c|c|c|}
\hline Unit & Level & $\begin{array}{l}\text { Formal } \\
\text { Luthic } \\
\text { Tools }\end{array}$ & $\begin{array}{l}\text { Cores } \\
\text { and } \\
\text { Early- } \\
\text { Stage } \\
\text { Bifaces }\end{array}$ & $\begin{array}{c}\text { Expedient } \\
\text { Lthic } \\
\text { Tools }\end{array}$ & Flakes & $\begin{array}{l}\text { Chips } \\
\text { and } \\
\text { shatter }\end{array}$ & $\begin{array}{c}\text { Ground } \\
\text { Stone }\end{array}$ & $\begin{array}{l}\text { bone } \\
\text { and } \\
\text { shell }\end{array}$ & $\begin{array}{l}\text { historic } \\
\text { artifacts }\end{array}$ & $\begin{array}{c}\text { Totals } \\
\text { by } \\
\text { Level }\end{array}$ \\
\hline \multirow[t]{6}{*}{ TU6 } & 1 & 0 & 0 & 0 & 0 & 2 & 0 & 0 & 0 & \multirow{6}{*}{$\begin{array}{l}2 \\
2 \\
16 \\
18 \\
1 \\
7\end{array}$} \\
\hline & 2 & 0 & 0 & 0 & 1 & 1 & 0 & 0 & 0 & \\
\hline & 3 & 0 & 0 & 1 & 13 & 2 & 0 & 0 & 0 & \\
\hline & 4 & 0 & 1 & 0 & 12 & 5 & 0 & 0 & 0 & \\
\hline & 5 & 0 & 0 & 0 & 1 & 0 & 0 & 0 & 0 & \\
\hline & 6 & 0 & 0 & 0 & 1 & 5 & 0 & 1 & 0 & \\
\hline \multicolumn{2}{|l|}{$\begin{array}{l}\text { Totals by } \\
\text { Class }\end{array}$} & 0 & 1 & 1 & 28 & 15 & 0 & 1 & 0 & 46 \\
\hline \multirow{6}{*}{$\begin{array}{l}\text { TU7 } \\
\left(0.25 \mathrm{~m}^{2}\right)\end{array}$} & 1 & 0 & 7 & 0 & 0 & 7 & 7 & 7 & 7 & \multirow{7}{*}{$\begin{array}{l}0 \\
0 \\
6 \\
3 \\
1 \\
2 \\
12\end{array}$} \\
\hline & $\frac{1}{2}$ & 0 & 0 & 0 & 0 & 0 & 0 & 0 & 0 & \\
\hline & 3 & 0 & 0 & 0 & 6 & 0 & 0 & 0 & 0 & \\
\hline & 4 & 0 & 0 & 0 & 1 & 2 & 0 & 0 & 0 & \\
\hline & 5 & 0 & 0 & 0 & 1 & 0 & 0 & 0 & 0 & \\
\hline & 6 & 0 & 1 & 0 & 1 & 0 & 0 & 0 & 0 & \\
\hline $\begin{array}{l}\text { Totals by } \\
\text { Class }\end{array}$ & & $\overline{0}$ & 1 & $\overline{0}$ & 9 & 2 & $\overline{0}$ & 0 & $\overline{0}$ & \\
\hline
\end{tabular}

\subsubsection{Feature Descriptions}

A total of seven features were identified in the backhoe trenches and test pits excavated on $41 \mathrm{WB} 437$.

Feature 1 was originally encountered during excavation of BT 1. The portion of the feature exposed by the machine consisted of a scatter of relatively small burned sandstone fragments, mussel shell fragments, and charcoal at $185 \mathrm{cmbs}$. The feature was cut through with the backhoe, revealing a very shallow $(1-2 \mathrm{~cm})$, weakly fired basin roughly $80 \mathrm{~cm}$ across. Informal investigation of the remainder of Feature 1 was accomplished by cleaning and excavating approximately about $10 \mathrm{~cm}$ (roughly 180-190 cmbs) of an area of approximately $140 \mathrm{~cm} \times 110 \mathrm{~cm}$ on an adjacent bench. This excavation yielded an unorganized scatter of burned sandstone pieces $(n=27)$ ranging f r $0 \mathrm{~m} 2 \mathrm{~cm}$ to $12 \mathrm{~cm}$ in size mounding a second diffuse, broadly oval burned zone approximately $25 \mathrm{~cm}$ in diameter. Two mussel shells, a large, crude bifacially-flaked cobble, an early-stage biface fragment approximately ten pieces of debitage (including two utilized flakes), and several land snail shells were also associated with the scatter. A charcoal sample collected from Feature 1 yielded a corrected AMS radiocarbon age of 3240 +/-50 BP, suggesting that it is Middle Archaic in age.

Feature 2 was detected during excavation of BT 3, and was not recorded in detail. It consisted of a few small $(<8 \mathbf{~ c m})$, angular fragments of burned sandstone associated with one end of a diffuse, lightly charcoal flecked stain measuring roughly 90 $\mathrm{cm} \times 160 \mathrm{~cm}$. The feature was detected at a depth of $25 \mathrm{~cm}$ in the backhoe trench, and was trowelled briefly before the trench was continued. As the bucket slowly peeled away 


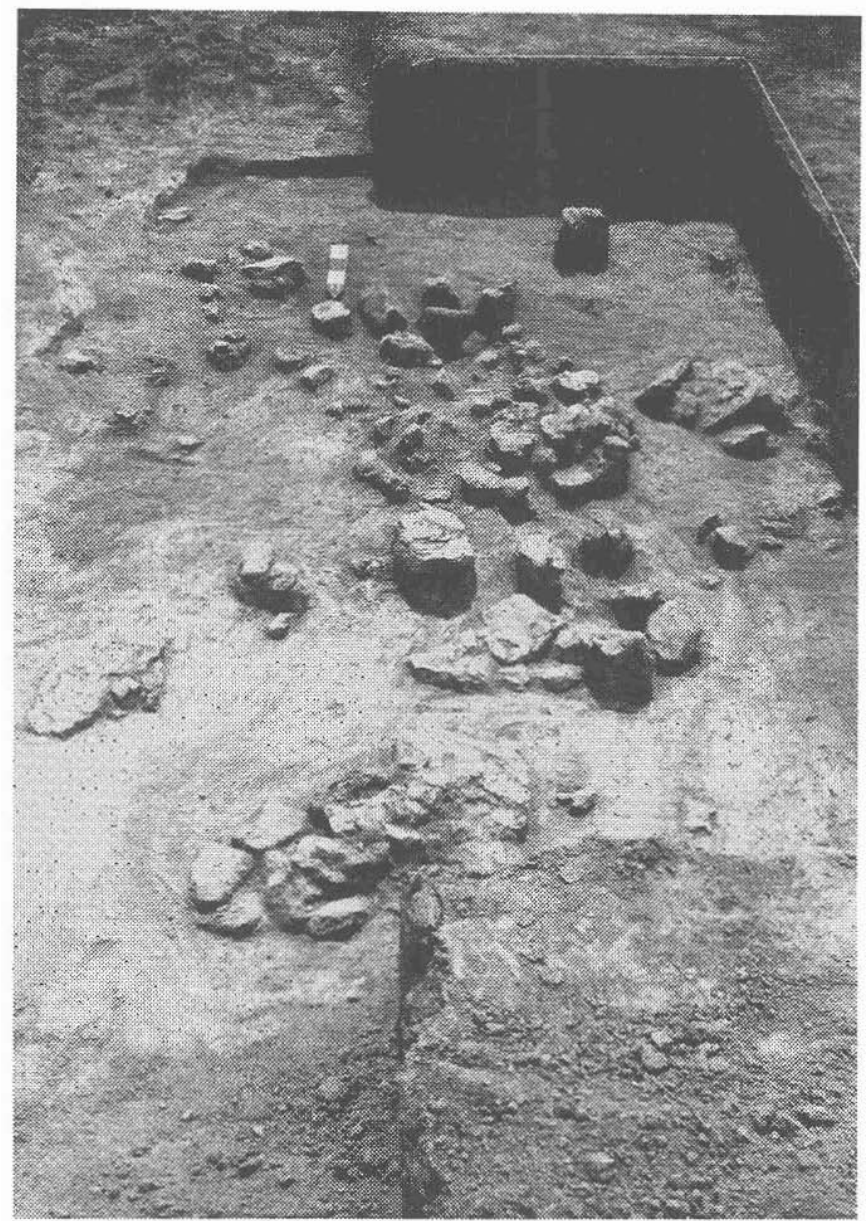

Figure 8: Photograph of Feature 3 at $40 \mathrm{cmbs}$, looking southeast. Note discrete stack of burned rock in the foreground and the stacked, dipping slabs to the south of the central feature.

the next $20 \mathrm{~cm}$ of sediment, the large oval stain gradually shrank to two oval stains $40-50 \mathrm{~cm}$ in diameter and roughly $25 \mathrm{~cm}$ apart. Given that a natural bum was noted at approximately this depth in TU5-7, the unusual shape of this feature may indicatea natural origin. In any event, no cultural material other than bumed sandstone was noted in association with Feature 2.

Feature 3 was detected at a depth of approximately $30 \mathrm{~cm}$ in BT2, and was subsequently exposed by the small block formed by TU1, TU 2, TU 3, and TU 4. This feetureconsists of a ro ugh semi-circleof approximately 140 sandstone clasts rangingfrom a few $\mathrm{cm}$ to more than 20 $\mathrm{cm}$ in maximum dimension interspersed with charcoal and burned earth (Figure 8). The entire feature measured approximately $2.7 \mathrm{~m} \mathrm{~N}-\mathrm{S}$ by $2.4 \mathrm{~m} \mathrm{E}-\mathrm{W}$. The nucleus of the feature was characterized by relatively smallclasts and abundantcharcoal, and there were severalclusters of larger, stacked slabs to the north and west(Figure9). Several of the slabs on the western side of the hearth were inclined toward the center of the feature. Most of the slabs wereheat-reddened, although a few were a dark gray that probably represents a reducing atmosphere. Artifacts recovered from the levels containing the feature (Levels 3 and 4) consist of approximately 12 pieces of debitage, one small biface,and a small quantity of highly fractured bone and shell 




Figure 9: Plan view of Feature 3 at 40 anbs.

from TU 3 on the southern side of the feature. A corrected radiocarbon age of $2060+/-$ $80 \mathrm{BP}$, indicating a Late Archaic affiliation, was obtained from the feature.

Feature 4 consisted of a small cluster of burned sandstone slabs that was exposed from 13-20 cmbs in TU 2 and TU 3. This small cluster consisted of about five slabs ranging fiom $4 \mathrm{~cm}$ to $16 \mathrm{~cm}$ in maximum dimension. The cluster as a whole occupied an area of approximately $30 \mathrm{~cm}$ in diameter. The cluster was situated directly over the center of Feature 3, and was separated fiom it by approximately $10 \mathrm{~cm}$ of fill. Unlike Feature 3, Feature 4 consisted of only burned rock with no associated charcoal. A small debitage assemblage, totaling 21 items fiom the four surrounding units, was associated with Feature 4.

Feature 5 consisted of a small cluster of burned sandstone slabs detected in the northeast comer of TU 5 between 50 and $60 \mathrm{cmbs}$. It was fully exposed by the contiguous excavation of TU 5, 6, and 7 (Figure 10). The feature consisted of a cluster of eight burned sandstone rocks ranging fiom 5 to $20 \mathrm{~cm}$ in maximum dimension, a secondary cluster of two burned slabs measuring 10-15 cm in maximum dimension 


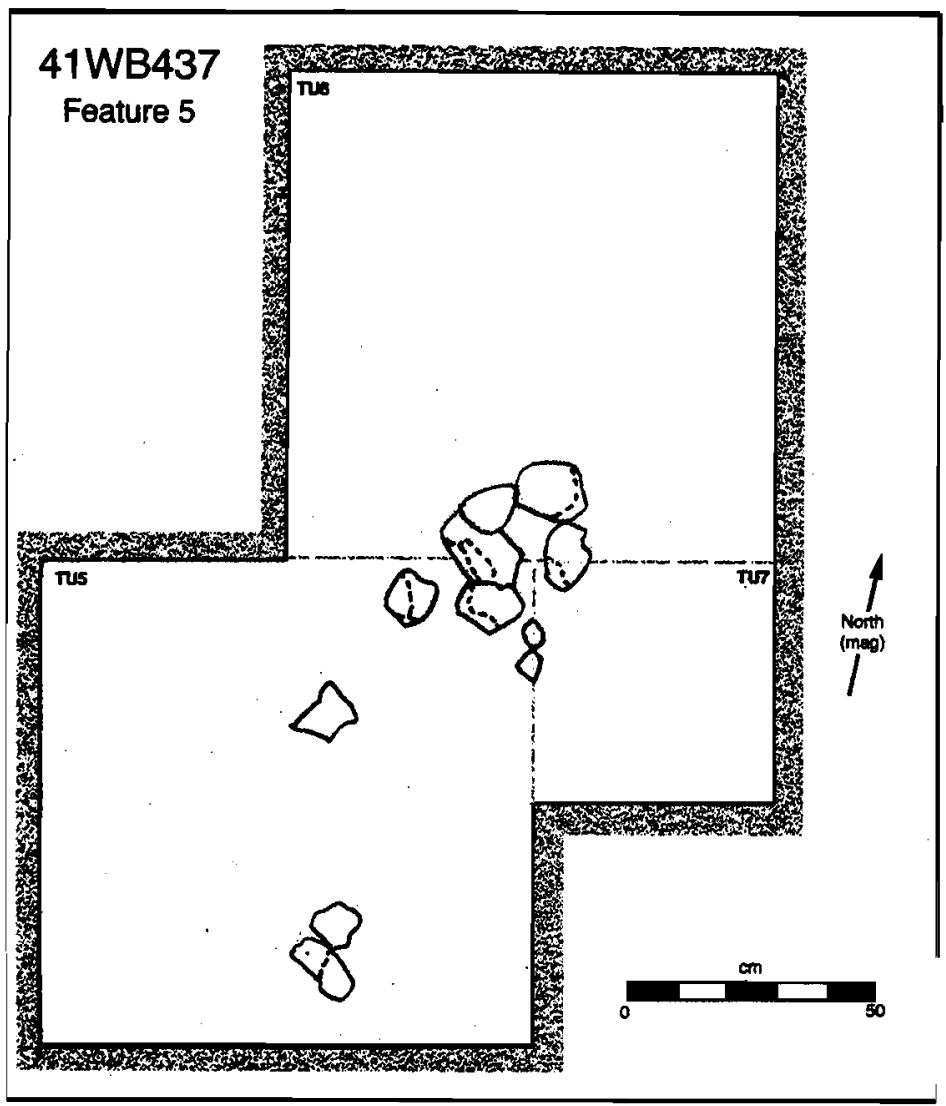

Figure 10: Plan view of F eature 5 at $60 \mathrm{cmbs}$.

situated $60 \mathrm{~cm}$ to the south, and a third locus occupied by a single burned slab between the two clusters. No charcoal was noted in association, and associated artifacts consisted of 10 pieces of lithic debitage.

Feature 6 was exposed in the wall of BT 1 at a depth of approximately $80 \mathrm{~cm}$ below the surface. It consisted of an amorphous concentration of heat-reddened sandstone and charcoal approximately $10 \mathrm{~cm}$ thick and 50-60 cm across. No associated artifacts were noted in the profile, but the feature was not investigated with a hand unit. A charcoal sample extracted from the wall yielded a corrected radiocarbon age of $2130+/-$ $40 \mathrm{BP}$, indicating Late Archaic affiliation.

Feature 7 was noted in the wall of BT3. It consisted of a shallow, basin-shaped stain measuring approximately $60 \mathrm{~cm}$ across and $20 \mathrm{~cm}$ thick. It contained a few small (1-4 cm) angular chunks of reddened and blackened sandstone and a few small, dispersed flecks of charcoal. No artifacts were noted in association, but the feature was investigated only by cleaning and scraping in section. 


\subsubsection{Artifact Descriptions \\ Ground/Pecked Stone Artifacts}

Only one ground/pecked stone artifact was recovered from 41WB437. This implement, a small, lightly used hammerstone, was found on the ground surface. It consists of a discoidal stream cobble of pinkish quartzite measuring $8.0 \mathrm{~cm} \mathrm{x} 6.7 \mathrm{~cm} \mathrm{x}$ $3.2 \mathrm{~cm}$. There is a single lightly-damaged facet on the edge of the hammerstone. The size and shape of the cobble and the location of the battered surface suggests that the implement was used for precision impacts (possibly hard-hammer lithic reduction) and was held between the thumb and middle finger, with the index finger arched over the top of the artifact for support.

\section{Flaked Stone Artifacts}

A total of 160 flaked stone artifacts were recovered from surface collection and test units excavated on 41WB438. Six of these artifacts consisted of formal and informal tools, tool fragments, or tool preforms; 136 consisted of debitage produced by stone tool manufacture; and 18 consisted of thermally-shattered fragments of tool-quality lithic material.

\section{UnidentifiedProjectile Points and $B$ faces}

One thin, late-stage biface that may represent a relatively long, straight sided Catan point or preform was recovered from TU 3, Level 3, in association with Feature 3 (Figure 11). It is $3.3 \mathrm{~cm}$ long, $2.5 \mathrm{~cm}$ wide, and $0.5 \mathrm{~cm}$ thick, and manufactured from a light brown chert that appears to have been lightly heat treated. The biface is broken across the distal end in an abrupt hinge fracture that may be impact related.

A second late-stage biface made from lustrous reddish gray chert was recovered from Feature 1 (see Figure 11). This artifact, which is also broken perpendicular to the long axis, measures $4.3 \times 3.6 \times 1.3 \mathrm{~cm}$. However, most of the artifact is much thinner $(0.7-0.9 \mathrm{~cm})$; the thick portion is due to a "knob" on one face that is situated near the major break, and may have been what the knapper was attempting to remove when the break occurred. Notably, this artifact has extensive unifacial retouch and use damage on the rounded end opposite the break, indicating it was used as a cutting or scraping tool after failure of the preform.

The only other biface fragment is a very small, irregular chip that exhibits remnants of bifacial flaking, and appears to represent a biface edge fragment removed by hard hammer percussion. It is $2 \mathrm{~cm}$ long by $1 \mathrm{~cm}$ wide and triangular in cross-section. The parent material is a veined, gray chert.

\section{Tested Cobbles}

A large $(11.7 \times 9.5 \times 5.6 \mathrm{~cm})$ bifacially tested cobble was recovered from the area of Feature 1 in BT1. This artifact is composed of a fine-grained, pinkish gray porphyritic rock with angular, glassy inclusions, and probably represents an extrusive igneous rock originating in what is now New Mexico. One side of the cobble has been reduced to a crude edge by the removal of approximately seven bifacial flakes, making 
Figure 11: Bifaces recovered from 41W B437. (a) possible Catan point or preform; (b) heat-treated, late stage biface.

a

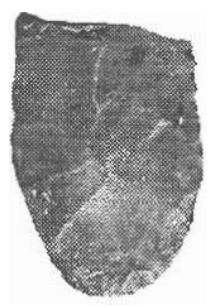

b

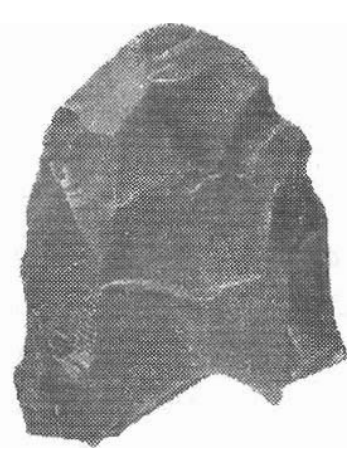

$0 \quad 10 \quad 20$

$\mathrm{mm}$ 
the artifact resemble a crude chopper or handaxe. However, the edge is undamaged, and it is likely that the artifact was tested for use as lithic raw material and rejected because the large inclusions made it fracture unpredictably.

\section{Modified Flake}

Two examples of edge-modified flakes were recovered from 41WB437. Specimen 1 consists of a large, heat-treated secondary flake of pinkish gray to pink banded chert measuring $3.5 \mathrm{~cm}$ by $4.6 \mathrm{~cm}$. The working edge of this implement is slightly convex and $3.2 \mathrm{~cm}$ long. It exhibits minimal bifacial pressure flaking and common small conchoidal, step, and bending fractures attributable to use-wear.

Specimen 2 consists of a small, expanding flake of opaque brown chert that has a pronounced hard hammer percussion bulge. The distal end terminates abruptly in a hinge fracture that suggests that the flake was much larger before it was snapped across the middle. The utilized edge is on one of the lateral flake margins, and has a relatively steep face due to the presence of an off-center flaking ridge on the dorsal surface. The edge shows no indication of intentional retouch, but does exhibit some minute bending fractures(Cottrell and Kamminga 1987).

\section{Debitage}

Almost 140 pieces of debitage were recovered from test excavations at 41WB437. More than half of this assemblage of debitage $(n=74)$ was recovered fiom Levels 3 and 4 in the block formed by TU 5-7. At least eight different raw materials are represented in this cluster, but it is dominated $(\mathrm{n}=33 ; 45 \%)$ by flakes of a relatively coarse, light brown opaque chert that may well represent reduction of a single core. Other raw materials occurring in the cluster include (1) pinkish brown to pinkish gray, heat treated chert, (2) relatively coarse, veined white chert, (3) medium brown, opaque chert, (4) dark brown, semi-translucent chert, and (5) one small example each of a red porphyritic material with quartz inclusions, coarse reddish brown quartzite, and moss agate. Similar materials were present in the remainder of the debitage assemblage. None of the materials are obviously exotic; however, the wide range of lithologies present in the diverse suite of Rio Grande lag gravels on the uplands would make such materials very difficult to recognize.

\section{Faunal Remains}

\section{Mussel Shell}

Two relatively complete mussel shell valves were recovered in association with Feature 1. Specimen 1 is a thick-bodied ovate shell that is consistent with a Salina Mucket (Potamilus salinasensis) (Howells 1994). It measures $7.5 \mathrm{~cm} \mathrm{x} 5.5 \mathrm{~cm}$ and weighs $28.58 \mathrm{~g}$. A second recovered shell is a thin, elliptical specimen consistent with an immature Texas Hornshell (Popenaias popei) (Howells 1994). It measures 4.4 x 2.0 cm and weighs $2.10 \mathrm{~g}$. Neither specimen is obviously cut or modified, although both exhibit some edge damage. 
Fragmentary mussel shell was noted in several backhoe trenches and recovered fiom TU 1, 3, 5, and 6. None of this material was identifiable to taxon.

Bone

The only bone recovered consisted of small fragments of an unidentified, relatively thick-walled element that was found in association with Feature 3 and a single unidentified rodent vertebra from Level 1 in TU 3. The total weight of the material associated with Feature 3 was less than 2 grams.

\section{Historic Artifacts}

Two historic artifacts were recovered from the test excavations. Specimen 1 consists of a short piece of coiled steel wire (probably baling wire) recovered from Level 2 in TU 1, and Specimen 2 consists of a .32 caliber handgun cartridge marked "U. S. C. Co." that was recovered from Level 1 in TU 3. Both of these items were recovered from near-surface context, and neither is indicative of significant disturbance of the site matrix.

\subsection{Results of Testing at $41 \mathrm{WB} 438$}

\subsubsection{Test Unit Descriptions}

Two test units, totaling $1.1 \mathrm{~m}^{3}$, were hand excavated on 41WB438. Test Unit 1 was situated on the beveled edge of the principal terrace and excavated to a depth of 60 cmbs. No features were noted in the unit, but cultural material was present to a depth of $50 \mathrm{cmbs}$. The profile exposed by the unit is similar to the upper profile exposed in BT2. It consists of primary and colluvially-reworkedalluvial of Unit 2. The colluvial deposits mantle the erosionally beveled margin of the terrace. In contrast to the uniformly silty sediments characterizing the relatively intact Unit 2 facies on 41WB437, the deposits in TP1 are slightly sandier and contain a considerable component of relatively fine, rounded stream gravel which occurs floating in isolation in the matrix and in thin, gently-dipping stringers. Relatively large quantities of debitage were recovered fiom the upper three levels (121 pieces; equivalent to 403 per $\mathrm{m}^{3}$ ), which appear to be largely colluvial in origin (Table 3). Artifact concentration fell off to negligible quantities in the lower three levels ( 4 pieces; equivalent to 13 per $\mathrm{m}^{3}$ ). The high quantities of debitage in the upper, colluvial fill almost certainly represent lag concentration of artifacts from the broader terrace surface.

Test Unit 2 was situated on the T1 surface near BT 1, and was excavated to a depth of $50 \mathrm{cmbs}$. The profile was similar to the upper profile of BT 1, consisting of relatively featureless dark yellowish brown to brown loamy fine sand. Artifacts were strongly concentrated in the upper levels, falling off from 80 pieces in Level 1 to none in Level 4 (see Table 3). Based on the steep decrease in artifact frequency and the dense scatter of surficial material, it is likely that these near surface artifacts are turbated and stratigraphically compressed by sheet erosion of the surface, faunal turbation, and historic activity. 
Table 3: Artifact recovery by test pit and level, 41 WB438

\begin{tabular}{|c|c|c|c|c|c|c|c|c|}
\hline |Unit & Level & $\begin{array}{l}\text { Formal Lithic } \\
\text { Tools }\end{array}$ & $\begin{array}{c}\text { Cores and } \\
\text { Earty-Stage } \\
\text { Blfaces }\end{array}$ & $\begin{array}{l}\text { Expedient } \\
\text { Lthic Tools }\end{array}$ & Flakes & $\begin{array}{l}\text { Chips and } \\
\text { shatter }\end{array}$ & $\begin{array}{l}\text { Ground } \\
\text { Stone }\end{array}$ & $\begin{array}{c}\text { Totalsby } \\
\text { Level }\end{array}$ \\
\hline \multirow[t]{6}{*}{ TU1 } & 1 & 0 & 3 & 0 & 20 & 18 & 0 & 41 \\
\hline & 2 & 0 & 0 & 1 & 15 & 24 & 0 & 40 \\
\hline & 3 & 1 & 1 & 1 & $\overline{13}$ & 25 & $\overline{0}$ & 41 \\
\hline & 4 & 0 & 0 & 0 & 1 & 1 & 0 & 2 \\
\hline & 5 & 0 & 0 & 0 & 2 & 0 & 0 & 2 \\
\hline & 6 & 0 & 0 & 0 & 0 & 0 & 0 & 0 \\
\hline \multicolumn{2}{|c|}{ Totals by Class } & 1 & 4 & 2 & 51 & 68 & 0 & 126 \\
\hline \multirow[t]{5}{*}{ TU2 } & T & $\bar{T}$ & 1 & 0 & 34 & 44 & 0 & 80 \\
\hline & 2 & 2 & 0 & 1 & 16 & 15 & 0 & 34 \\
\hline & 3 & 0 & 0 & 0 & 8 & 1 & 0 & 9 \\
\hline & 4 & 0 & 0 & 0 & 0 & 0 & 0 & 0 \\
\hline & 5 & 0 & 0 & 0 & 0 & 0 & 0 & 0 \\
\hline \multicolumn{2}{|c|}{ Totals by Class } & 3 & 1 & 1 & 58 & 60 & 0 & 123 \\
\hline
\end{tabular}

\subsubsection{Artifact Descriptions}

\section{G round/Pecked Stone Artifacts}

\section{Abrader}

A sandstone abrader was recovered from the surface of 41WB438 (Figure 12-a). The artifact consists of a trapezoidal slab of reddish brown, iron-cemented fine-grained sandstone measuring approximately $15 \mathrm{~cm} \times 12 \mathrm{~cm} \times \mathbf{4} \mathrm{cm}$. Both faces of the abrader are cut with multiple deep grooves. One side exhibits four subparallel grooves varying from $6 \mathrm{~cm}$ to $11 \mathrm{~cm}$ in length and $0.5 \mathrm{~cm}$ to $1.0 \mathrm{~cm}$ in depth. All four grooves intrude from the same edge of the stone, and all but one terminate before reaching the other side. All of the grooves are distinctly $\mathrm{V}$-shaped in cross-section. The obverse side of the stone is dominated by three less-defined subparallel grooves approximately $9 \mathrm{~cm}$ long. These three grooves also intrude from one edge of the stone and terminate before reaching the other side, and are less than $0.5 \mathrm{~cm}$ deep. Two secondary grooves are also present on the margin of the stone. Both of these grooves intrude from the same edge at an angle of approximately $135^{\circ}$ from the origin of the primary grooves, and neither cuts across the more developed primaries. The longer of the two secondary grooves is approximately 6 $\mathrm{cm}$ in length and $\mathbf{0 . 2 5} \mathrm{cm}$ deep, while the other is approximately $2 \mathrm{~cm}$ long and $0.5 \mathrm{~cm}$ deep. The distinct V-shape of the grooves and the fact that none traverse the entire surface of the stone suggest that the abrader was probably used to sharpen an implement with an abrupt, acute edge rather than to smooth and shape a shaft. Similar implements have been interpreted as tools used to prepare edges during biface reduction and to modify bone and shell implements (Turner and Hester 1993: 287) . 
Figure 12: Sandstoneabrader (a) and quartzite hammerstone (b) recoveredfrom the surface of 41WB438.
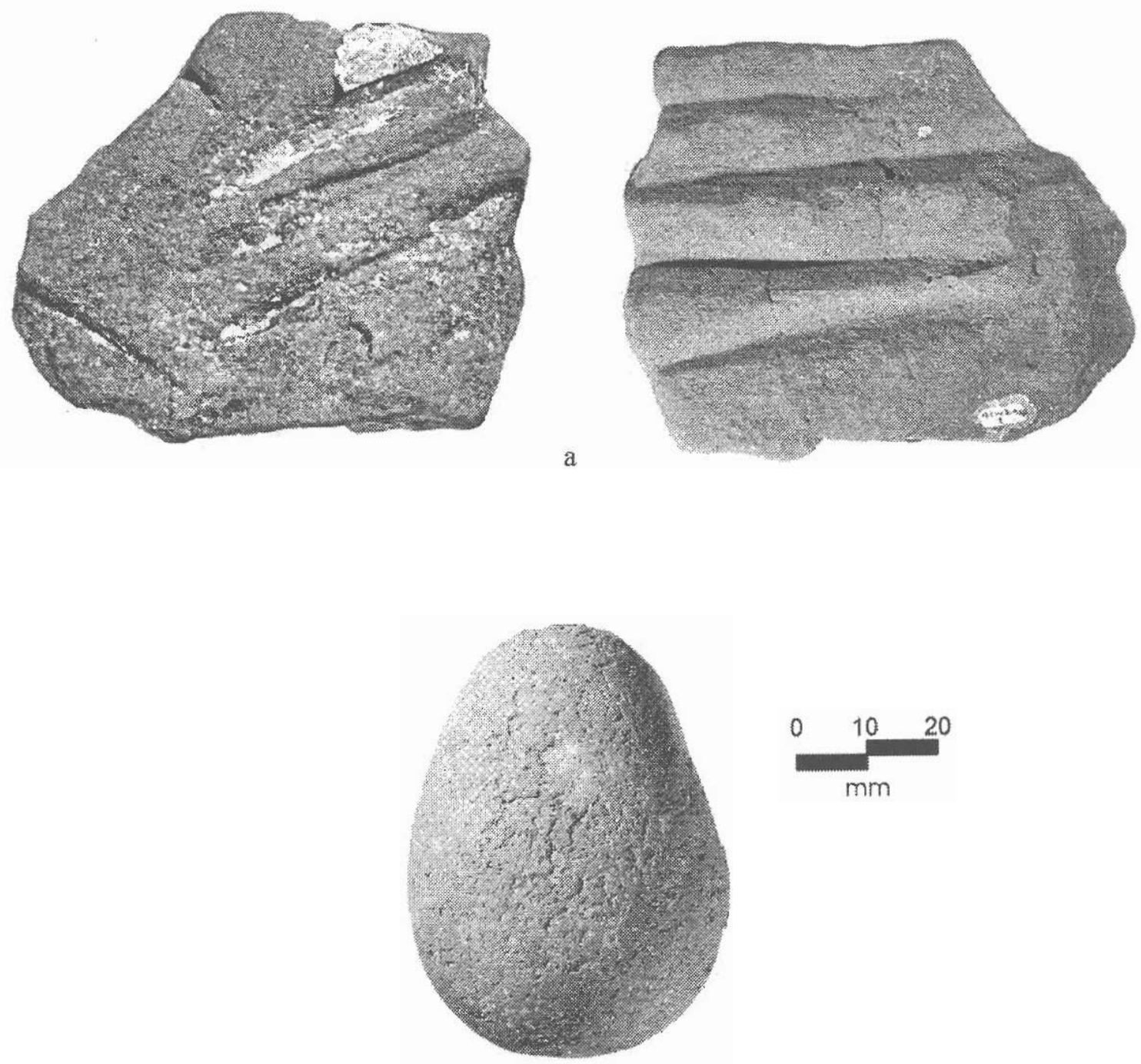

$\mathrm{mm}$ 


\section{Manos}

One broken mano made from a discoidal reddish quartzite river cobble was recovered from the surface (Figure 13-c). This artifact measures $10.0 \mathrm{~cm} \times 7.2 \mathrm{~cm} \times 4.3$ $\mathrm{cm}$. It is broken in two places on one side and exhibits battering damage in two places on the margin, suggesting that it was also occasionally used as a hammerstone. The upper surface is somewhat concave, while the grinding surface is slightly convex. Although use-wear is not pronounced, there are a series of subtle, parallel striations on the working surface oriented with the long axis of the artifact.

Another small mano (Figure 13-b), measuring $7.4 \mathrm{~cm}$ x $5.3 \mathrm{~cm}$ x $1.8 \mathrm{~cm}$, was also recovered from the surface. It is discoidal in shape and composed of a well-cemented tan sandstone. There are probable wear facets on both sides of the implement.

An unusual specimen that may represent a mano fragment was also recovered from the surface (Figure 13-a). This small, tabular fragment is composed of a purplish porphyritic quartzite, and appears to have been thermally-fractured. The slab is distinctly trapezoidal in cross-section. Two smoothed surfaces are situated on the sides of the fragment rather than on the larger faces. While the function of this small artifact is unclear, it may represent an abrading implement held between the thumb and forefinger.

\section{Hammerstone}

One ovoid hammerstone composed of purplish green quartzite was recovered from the surface (Figure 12-b). This artifact, which measures $11 \mathrm{~cm}$ x $8 \mathrm{~cm}$ and weighs $856 \mathrm{~g}$, exhibits battering damage on several faces, particularly on the more acute end.

\section{Flaked Stone Artifacts}

A total of 255 flaked stone artifacts were recovered from surface collection and test units excavated on 41WB438. Thirteen of these artifacts consisted of formal and informal tools, tool fragments, or tool preforms; 195 consisted of debitage produced by stone tool manufacture; and 47 consisted of thermally-shattered fragments of tool-quality lithic material.

\section{Projectile Points}

A basolo/Catan: Abasolo points are moderately-sized, triangular to leaf-shaped unnotched dart points with rounded bases. Catan points are smaller points that are otherwise identical to Abasolo. Both were first defined by Suhm, Krieger, and Jelks (1954) based on unpublished descriptions by R. S. MacNeish, who noted the similarity of the two types and described them in a 1958 publication. The Catan points may be of Late Archaic or Late Prehistoric age, while Abasolo points are believed to be exclusively Archaic (Turner and Hester 1993; Davis 1991).

One specimen of .anintact A basolo/Catan point recovered from the surface of 41WB438 (Figure 14-a). The specimen is made of a fine-grained, greenish brown quartzite and measures $4.9 \mathrm{~cm} \times 2.3 \mathrm{~cm}$ with a maximum thickness of $0.8 \mathrm{~cm}$. It exhibits 
Figure 13: Manos and mano fragments recovered from the surfaceof 41WB438.
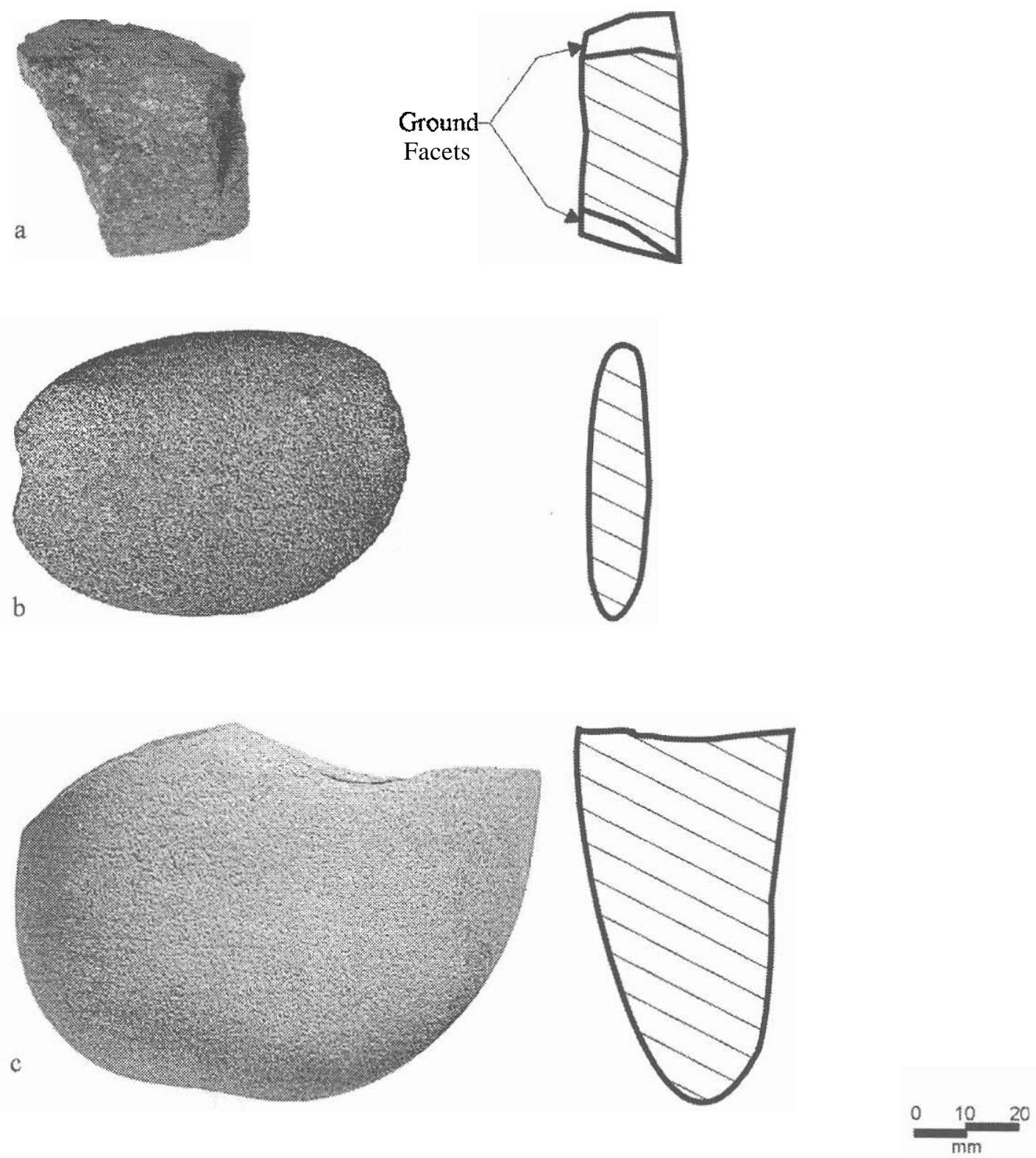
Figure 14: Bifacialand unifacial tools and tool preformsrecoveredfrem the surface of 41WB438.(a) A basolo/ Catanpoint, (b) LozengePoint, (c) Kinney Point, (d) untyped triangular point,(f, g) probable Kinney preforms, $(\mathrm{e}, \mathrm{h})$ thick bifaces, (i) unifacial scraper (possible Nueces tool).

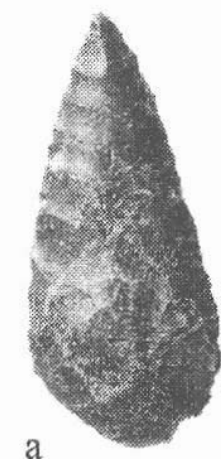

a

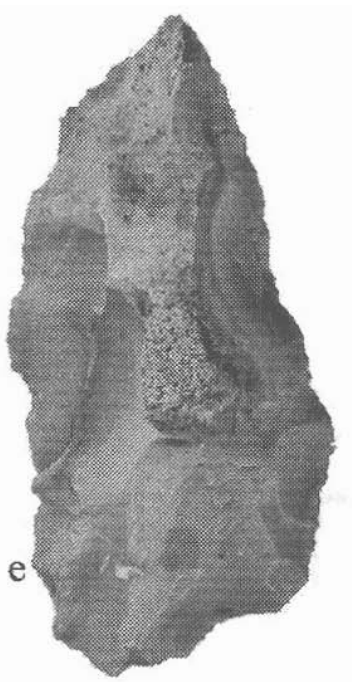

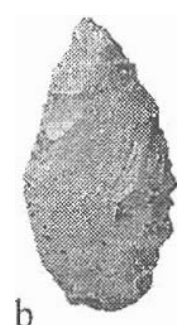

b

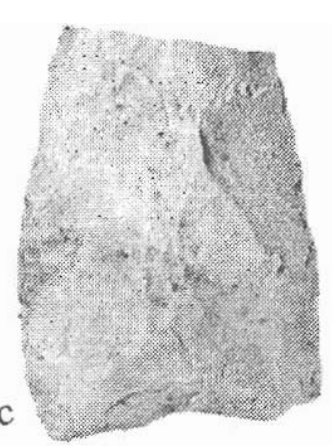

d

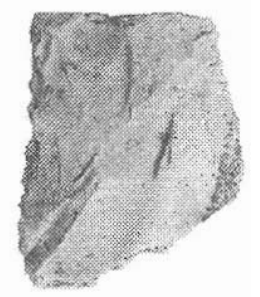

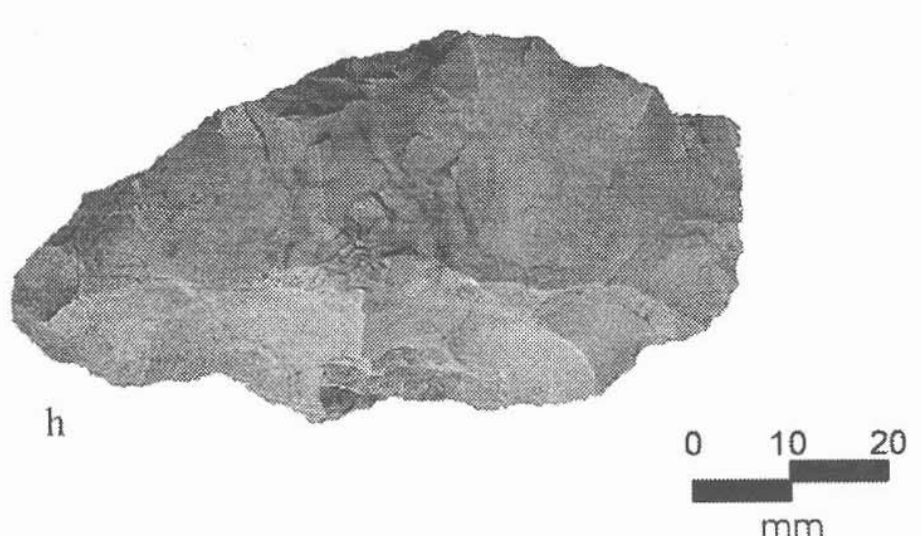

$\mathrm{mm}$

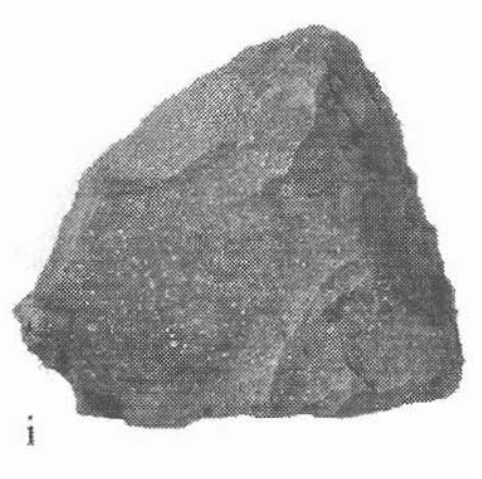


fine bifacial flaking, slightly convex edges, and a rounded base that has been thinned on one side by the removal of two wide, subparallel flakes during the last stage of manufacture. Glen Goode (personal communication) notes that the base has a cruder, more unfinished aspect than the remainder of the point, suggesting that it may have been reworked from a different style. Although the length of the point exceeds the dimensions MacNeish (1958) described for Catan points by nearly a centimeter, it is similar to the size of several Catan examples illustrated by Suhm and Jelks (1962), Turner and Hester (1993), and Davis (1991), and is smaller than most of the illustrated Abasolo points.

Lozenge: Lozenge points are small, oval to diamond-shaped unnotched arrow points typical of the lower Texas coast (Turner and Hester 1993). They are distinctive in that one end is worked using a distributed bifacial reduction process, resulting in a lenticular cross-section, while the other end is alternately beveled, resulting in a diamond-shaped cross-section. They are believed to be Late Prehistoric in age (Turner and Hester 1993). Although Lozenge points are not typical of the Laredo area, the distinctive manufacturing technique makes identification relatively straight-forward.

One specimen of an intact Lozenge point was recovered from the surface at 41WB438 (Figure 14-b). The specimen is leaf-shaped in outline, and exhibits the distinct beveling on one end typical of the type. It is composed of a somewhat waxy tan chert that verges on pinkish-tan in places, and probably represents heat-treated material. The point measures $3.1 \mathrm{~cm} \times 1.55 \mathrm{~cm}$, and has a maximum thickness of $0.6 \mathrm{~cm}$ on the beveled end and $0.4 \mathrm{~cm}$ on the bifacially worked end. The bifacially worked end is rounded, while the beveled end is longer and relatively acute, suggesting that it was the working (distal) end of the artifact. The beveling is pronounced on one face and moderate on the other, and may represent resharpening of a halfted point.

Kinnev: Kinney points are relatively large, unstemmed triangular points that occur from the Edwards Plateau south into south Texas and west into the eastern Trans-Pecos (Prewitt 1995). They are elongate, with typically convex edges and a shallowly to moderately concave base. Turner and Hester (1993) suggest that they date primarily from the Middle Archaic subperiod.

One proximal/medial fragment of a completed Kinney point and two late-stage biface fragments that probably represent Kinney preforms were recovered from the surface at 41WB438 (Figure 14- c). Specimen 1, the completed point fragment, is made from a mottled, opaque gray-brown chert that has developed a pronounced, light brown patina. The fragment is $3.3 \mathrm{~cm}$ wide and $4.3 \mathrm{~cm}$ long, and has a maximum thickness of $0.8 \mathrm{~cm}$. The edges are slightly convex and exhibit step-fractures on alternating sides indicative of relatively careless unifacial retouch. Extrapolation of the edges suggests that the point was originally 7 to $8 \mathrm{~cm}$ long. A relatively long and wide (approx. $3 \mathrm{~cm} \mathrm{x}$ $1.2 \mathrm{~cm}$ ) basal channel flake was removed during the last stage of initial manufacture, thinning the base relative to the medial section. Although the break appears impactrelated, the broken face is somewhat less patinated than the exterior, and a cross-section 
of a patina approximately half a millimeter thick is visible at the break. This suggests that the point was reused and broken some time long after its original manufacture.

Specimen 2 (Figure 14-f) consists of a late-stage biface fragment manufactured from a light brownish-gray chert containing many fine black inclusions and a few sandsize white quartz inclusions The fragment is $3.7 \mathrm{~cm}$ wide, $3.5 \mathrm{~cm}$ long, and $0.7 \mathrm{~cm}$ thick, and has been shaped into a rough approximation of a Kinney base. The edges are unfinished, and the break consists of a shallow hinge fracture, suggesting that the preform failed during the last stages of thinning.

Specimen 3 (Figure 14-g)consists of a somewhat larger (4.5 cm x 4.5 cm x 1.2 cm) biface fragment composed of light grayish-brown chert. It is still relatively thick and was obviously broken during thinning. Although the conclusion that this biface represents a Kinney preform is conjectural, the form is consistent with the type. Unlike the other two Kinney specimens, Specimen 3 exhibits little evidence of patination, suggesting that it may have been buried until relatively recently.

Unidentified Projectile Points and Bifaces: One unidentified projectile point fragment, three late-stage biface fragments, and four crude, early stage biface fragments were recovered from 41WB438. The projectile point fragment (see Figure 14-d) consists of the basal section of a moderately sized, triangular dart point recovered from the surface. The point is made from an apparently light brown to yellowish-white chert containing small dark inclusions concentrated in several subparallel bands. It is heavily patinated, and it is quite possible that the true color of the chert is considerably darker. The edges of the point expand toward the base, which is shallowly notched. The distal half of the point and one of the wide tangs created by the basal notch are missing. Both breaks are relatively flat surfaces, and it is unclear whether damage to the point was use-related or occurred during rejuvenation. This damage is clearly not the product of primary production, as one of the edges exhibits a series of small, sequential step-fractures indicative of expedient resharpening. The existing artifact has maximum dimensions of $2.9 \mathrm{~cm} \times 2.4 \mathrm{~cm}$ and a maximum thickness of $0.5 \mathrm{~cm}$. Based on extrapolation of the trends of the preserved edges, the original dimensions of the point appear to have been at least $6.5 \mathrm{~cm} \times 2.6 \mathrm{~cm}$. Although not enough of the point remains for a confident identification, this specimen may represent another, somewhat smaller Kinney point.

Three late-stage biface tips were recovered from the two test pits on 41WB438. Specimen 1 was recovered from TU 1, Level 3. It represents the tip of what was probably a relatively large and heavy biface separated by a clear impact failure. The small tip measures $2.3 \mathrm{~cm}$ long, $1.9 \mathrm{~cm}$ wide and $0.85 \mathrm{~cm}$ thick. It is made of smooth, tan chert and is very lightly patinated on one side only.

Specimen 2 represents a larger tip fragment composed of mottled to irregularly banded pink and gray fossiliferous chert recovered from Unit 2, Level 1. The material exhibits a glassy to soapy luster and is almost certainly heat-treated. The fragment 
measures $4.2 \mathrm{~cm}$ long by $4.0 \mathrm{~cm}$ wide, and is $1.0 \mathrm{~cm}$ thick. It exhibits no pressure flaking or retouch and was probably broken during manufacture.

Specimen 3 consists of a large biface tip recovered from Unit 2, Level 2. It is composed of mottled tan chert and also exhibits the soapy texture commonly attributed to heat treatment. Although the separation is a clear hinge fracture and there is minimal retouch apparent on the extant edges, it is likely that this specimen was also broken during manufacture.

Four relatively crude early-stage bifaces and biface fragments were also recovered from 41WB438. Specimen 1, which was found on the surface, consists of a squat, thick biface measuring $7.8 \mathrm{~cm}$ long, $3.8 \mathrm{~cm}$ wide, and $2.7 \mathrm{~cm}$ thick (Figure 14- h). Most of this thickness is due to a knob on the center of one side. The artifact is composed of coarse-grained, veined gray chert and clearly represents reduction of a core.

Specimen 2, also a surface find, is a triangular fragment measuring $5.6 \mathrm{~cm} \times 2.4$ $\mathrm{cm} \times 1.9 \mathrm{~cm}$ that represents the early stages of core reduction. It is composed of fossiliferous greenish-brown chert and retains vestiges of reddened cortex, suggesting that it was also heat treated. Specimen 3, from Level 2 in Unit 2, consists of a fragment of opalized wood measuring $5.5 \mathrm{~cm} \times 5.5 \mathrm{~cm} \times 1.6 \mathrm{~cm}$. It represents a large core reduction flake with minimal modification of the ventral surface. The dorsal surface is crazed with a number of randomly-oriented fractures that clearly represent heat treatment. Specimen 4, another surface find, consists of a bifacially-reworked hard hammer flake (Figure-e). It measures $7.3 \mathrm{~cm}$ x $3.4 \mathrm{~cm} \times 1.6 \mathrm{~cm}$. The dorsal surface is modified at the distal end by the removal of approximately five flakes that provide minimal shaping, while the medial and proximal parts of the dorsal surface retain cortex and appear relatively unmodified since flake detachment. The ventral surface is also shaped by the removal of approximately six flakes. A short length of the more heavily modified end of the artifact exhibits unifacial retouch along one edge, suggesting that the artifact was used briefly as a scraper.

\section{Unifacial Tools}

The only formal unifacial tool recovered was found on the surface. It consists of a roughly triangular scraper measuring $4.5 \mathrm{~cm} \times 4.1 \mathrm{~cm} \times 1.0 \mathrm{~cm}$ that is constructed from a hard-hammer secondary flake (Figure 14-i ) and is similar to descriptions of the Nueces tool (Turner and Hester 1993). The material consists of greenish-brown opaque chert with distinct white speckles that probably represent microfossil inclusions. A small area of yellowish cortex remains on part of the striking platform. There is one well-developed working edge on the artifact at the distal end of the dorsal surface. The working edge is relatively steep (approximately $55-70^{\circ}$ ) and faced with a series of very small step fractures that probably represent use-wear.

Two of the recovered flakes exhibit unifacial retouch and/or use wear. Edge modified flakes were present in TU1, Level 3, and TU2, Level 2. Both flakes exhibited minimal modification of only one edge. 


\section{Debitage and Thermal Shatter}

A wide variety of lithic material is represented in the debitage from Test Units 1 and 2. The material is dominated by tan and light gray cherts, but also includes siltstone, quartzite, chalcedony, and a variety of metamorphic rocks. Discoloration and/or waxy surface texture indicative of heat alteration is apparent in approximately $20-25 \%$ of the flakes. None of the materials appear to represent lithic resources that are not available on the surrounding upland as a gravel lag. 


\section{SUMMARY, ELIGIBILITY DETERMINATIONS, AND RECOMMENDATIONSFOR FURTHER WORK}

\subsection{Summary and Eligibility Determinations}

Sites 41WB437 and 41WB438 are two prehistoric sites situated on opposing terraces of a small tributary feeding into the Rio Grande River in the vicinity of Laredo, Texas. Geomorphic evaluation of the setting suggests that both sites formed on the same point bar on the south side of the stream, and were subsequently separated when the channel transected the surface. Site 41WB438, on the south side of the modern channel, is underlain by a probable Pleistocene fill (Unit 1) that forms the core of the older part of the point bar and a 50-100 cm drape of more recent, Holocene deposits (Unit 2). These latter sediments thicken considerably to the north, so that $41 \mathrm{WB} 437$ is underlain by at least $3 \mathrm{~m}$ of clearly stratified silts and silt loams related to Unit 2.

Site 41WB438 is littered with lithic material and groundstone that occurs on the surface and, particularly, in broad, shallow depressions resulting from headwardadvancing pockets of active sheet erosion. Recovered diagnostics are indicative of Archaic and Late Prehistoric components. However, the results of testing indicate that archeological remains are absent at depth. Moreover, while the upper strata are relatively rich in exposed and near-surface archeological material, the site lacks contextual integrity due to the combined effects of sheet erosion, historic impacts, and natural turbation processes. Therefore, no impact will result from planned highway construction (per CRF 800, subsection 800.9.a), and no additional work is recommended in the U.S. Highway 83 R-O-W. However, because the visible surface scatter extends west beyond the R-O$\mathrm{W}$ fence into an area where thicker Holocene deposits are likely, the site as a whole cannot be considered ineligible for listing on the National Register of Historic Places or for designation as a State Archeological Landmark. If future construction beyond the R$\mathrm{O}-\mathrm{W}$ fence is proposed at some later date, the potential impact on that portion of the site would require further evaluation.

In contrast, 41WB437 appears to represent the remains of a number of relatively short-term activity surfaces dating to the Archaic Period that were occupied and sealed by flood deposits of San Idelfonso Creek. The thick fill on the site contains buried burned rock features containing considerable charred material, as well as a large number of dispersed burned sandstone clasts throughout the fill. While the isolated burned rocks indicate that some archeological strata were disrupted and strewn across the point bar

surface by high magnitude flooding, the presence of abundant charcoal in preserved features suggests that others were buried by lower-magnitude flows with little erosive power. Such buried surfaceshave considerable potential to contain data relevant to questions of subsistence and logistical behavior within a tightly constrained temporal framework. As such, 41WB437 is considered eligible for the National Register of Historic Places under Criterion D of the federal regulations outlining criteria for evaluation (36 CFR 60). 


\subsection{Recommendations for Further Work}

\subsubsection{Research Questions}

The location of 41WB437 and 41WB438 is an ideal staging area for access to the Rio Grande terraces and floodplain and to the uplands flanking the late Pleistocene1 Holocene Rio Grande valley, which are mantled with an abundant, diverse lag of moderate to high quality lithic raw material. Although modern flow of San Idelfonso Creek is ephemeral, it would have served as a convenient water source, at least on a temporary basis, during the prehistoric period. In addition, the incised valley would serve as an efficient conduit for access to upland areas away from the Rio Grande, particularly given the dense thorn brush that occupies much of the upland, and may have also been a locus for exploitation of specific faunal and/or floral resources concentrated in the tributary valley system. The question arises: what were people actually doing at the site? Is the same activity (or limited suite of activities) represented repeatedly in cultural stratum after cultural stratum, or are different activities represented at different times?

Site 41WB437 is an ideal site to address specific behavioral questions on the Rio Grande Plain, an area that is poorly understood (Black 1989; Hester 1995). It contains a number of discrete, stacked, isolable activity surfaces that probably represent relatively short-term behavior by a finite number of people. The ubiquity of such remains in the 41WB437 matrix is demonstrated by the rate of discovery during the limited testing phase -identifiable features were noted in three of the four backhoe trenches excavated on the site and in a single randomly-placed test pit excavated after completion of trenching. The presence of identifiable stratigraphy in the form of alternating beds of massive silt and structured silt loam provides the potential to correlate spatially-discrete, stratigraphically-relatedactivity loci with a high degree of precision and confidence. The presence of preserved features with associated charred ethnobotanical material, faunal remains, and lithic debris affords the opportunity to address a wide range of relevant technological, logistical, and subsistence-based questions.

So little is known about the Late Archaic in the Laredo area that it is difficult to identify tightly constrained research questions. In large part, the analytical focus must be flexible to accommodate opportunities arising from the suite of recovered data. Nevertheless, some basic research questions can be outlined that would be appropriate for examination at 41WB437. We recommend that these research questions and the methodology outlined in the final section be submitted to qualified bidders for proposal.

Subsistence: What economic remains are preserved at the site? Are there food remains associated with the burned rock features? If so, are similar resources associated with each occupation strata, or are there shifts apparent in the locally-exploited resource base? Are the resources represented diverse, or was a limited, specific suite of resources being targeted for exploitation at this locality? Do these resources have a seasonal implication, 
and if so, does it hold for multiple occupation strata? Are non-local food resources, such as deep-water mussels indicative of procurement in the Rio Grande, present?

Data Requirements

Edible macrobotanical and faunal remains; food residues.

Lithic Resource Procurement and Technology: Was lithic procurement and reduction an important'activity at 41WB437? Are the features related to heat treatment of locally procured lithic raw material? What stages of lithic production are represented? Are discrete assemblages that can be used to infer reduction sequences and strategies present, and if so, what inferences can be drawn? Are tools apparently being made and discarded on site, or were most finished tools taken away? Is the portion of the represented spectrum of lithic reduction indicative of very short visits or longer occupations?

\section{Data Requirements}

Recovery of lithic debitage; assessment of upland lithic variability through collection of specimens.

Burned Rock Technology and Data Content: What intensity of use and/or frequency of reuse is indicated by the burned sandstone clasts? What function(s) are represented by the features? How are the features constructed? Is there evidence of repeated use of individual features? If so, does more rock seem to be added with subsequent uses (i.e., are rocks cycled through the feature)? What fuel is represented? How diverse is the fuel associated with individual features? Are archeomagnetic techniques suitable for determining the cooling history and relative cooling position of burned sandstone clasts at 41WB437, and if so, what do they indicate about feature context and cooling history? Can burned sandstone clasts at $41 \mathrm{WB} 437$ be dated reliably using thermoluminescence techniques?

Data Requirements

Feature recovery; replicative experiments with heated sandstone; archeomagnetic sampling and analysis; collection and analysis of paired charcoal and thermoluminescencedating samples.

\section{Site Structure and Organization:}

Are discrete activity areas preserved, and if so, what do they represent? Are activities segregated on site? How large are the individual components (i.e., how many stratigraphically-related features are present in each identified cultural stratum)?

Data Requirements

Broad exposure, recovery of multiple, stratigraphically related features and/or activity loci. 
Chronology and Cultural Affiliation:

What are the ages of the archeological phenomena present? What diagnostic artifacts are associated with each identified stratum? What activities are represented, and in what intensity? Do artifacts of the triangular point tradition (e.g., Abasolo, Catan) co-occur with artifacts of the stemmed point tradition (e.g., Marcos, Ensor)? Are exotic artifacts (e.g., marine shells) present, and if so, what are they associated with?

Data Requirements

Radiocarbon analyses, diagnostic artifacts, subsistence remains.

PaleonvironmentalStudies:

What do the remains indicate about evolution of the surrounding landscape? What are the isotopic attributed of recovered food and fuel remains? What is the isotopic character of site sediments and snail fauna? What are the geomorphic implications of the site deposits, particularly for the severity and recurrence interval of flooding?

Data Requirements

Isotopic analyses of sediments, snail shells, bone, mussel shell, and macrobotanical remains. Textural analysis of site sediments. Architectural assessment of the sequence of site deposits.

Site Formation Processes:

What is the character of primary sedimentation and disturbance processes on the site? Is the entire sequence alluvial in origin, or are eolian deposits present as interbeds? What agents of disturbance are represented, and what is their extent and severity? What processes are represented by the complex structure of the silty loam deposits? What inferences can be made about the potential for site preservation elsewhere in the region?

Data Requirements

Detailed recording of stratigraphy, textural analysis, micromorphological analysis.

\subsubsection{Methodology}

The opportunity for theoretical advancement presented by $41 \mathrm{WB} 437$ is matched by logistical and budgetary disadvantages. Because the individual occupations are relatively ephemeral and exhibit a paucity of associated remains, extensive excavation is required both to understand the spatial structure of the site (and the patterning of activities within that structure) and to recover a sufficient amount of artifactual material for meaningful analysis. Addressing such a problem with traditional, grid-based hand excavation methods is a costly, time-intensive prospect. A viable alternative approach is exemplified by excavations on the W urzbach Parkway in San Antonio (Black, Frederick et al. 1997; Black, Karbula, et al. 1997), which utilized machine excavation coupled with a total data station to rapidly excavate and record a broad area of an archeological site.

The Wurzbach exercise admittedly met with mixed success (Black, Frederick et al. 1997; Black, Karbula, et al. 1997), but this could be expected from any radically new 
innovation. Arguably, the lessons learned during the process resulted in marked improvements in the technique between the firstattempt (Black, Frederick et al. 1997) and the second (Black, Karbula, et al. 1997). Moreover, many of the difficulties encountered in the Wurzbach excavations were the result of factors that are quite different at 41WB437. Foremost among these was a highly compressed stratigraphy and a site matrix that was differentiatable only based on soils criteria (i.e., while the A horizon could be distinguished fiom the B horizon, no primary stratification was observable). Both of these factors are quite different at 41WB437. Other negative factors at Wurzbach, such as a dense clay loam matrix and a high density of cultural material, are also not a problem at $41 \mathrm{WB} 437$.

A modification of the techniques pioneered at Wurzbach (and in particular, at 41BX996) are proposed for mitigation of 41WB437. Excavation should focus on a single block of no less than $200 \mathrm{~m} 2(10 \mathrm{~m} \times 20 \mathrm{~m})$ from the surface to a depth of no less than $120 \mathrm{cmbs}$. Principal excavation should be accomplished by the removal of thin (1-2 cm) of slices of sediment with a gradall, with all noted artifacts point-plotted with the TDS. It is suggested that these excavations occur as a series of parallel trenches roughly $1.6 \mathrm{~m}$ wide separated by balks $40 \mathrm{~cm}$ wide. The effort should be made to take each trench down simultaneously, one natural unit (or "strat" in the Wurzbach parlance) at a time, in order to expose broad paleosurfaces and determine the relationship between artifacts. No effort should be made to run the entire matrix through hardware mesh. However, any features encountered, and the sediments within $1 \mathrm{~m}$ of the margin of the feature, should be excavated by hand. Sediment from areas outside the feature should be screened through 1/8" hardware cloth in the field, and all feature fill should be collected and floated to maximize recovery of small and fragile remains.

Following completion of the trenches, the remaining balks should be excavated to provide finer control on artifact content. Two collection strategies should be employed:

(1) Fifty column samples measuring $40 \mathrm{~cm} \times 20 \mathrm{~cm}$ by $120 \mathrm{~cm}$ (subdivided by natural levels) should be collected at $2 \mathrm{~m}$ intervals along each balk for bulk flotation; and

(2) The remainder of the balks should be excavated by natural levels and screened through 1/4" mesh in the field. The ability to access the balks from the side, where the stratigraphy is apparent, should allow the balks to be rapidly excavated. Where possible, recovered artifacts should be piece plotted, and the fill of any features present in the balks should likewise be bagged for flotation.

If these recommendations are followed, total volume excavated from the site during mitigation will be approximately $220 \mathrm{~m}^{3}$. Of this amount, at least $4.8 \mathrm{~m}^{3}$ will consist of flotation samples, while $43.2 \mathrm{~m}^{3}$ will have been screened in the field. This three-part approach to sampling will allow for high confidence evaluation of recovery rates from each method, while simultaneously facilitating rapid, efficient excavation of the site. 


\section{REFERENCES CITED}

Barnes, V. E.

1976 Geologic Atlas of Texas, Laredo Sheet. Bureau of Economic Geology, University of Texas at Austin.

Bement, L. C., and Y. M. Rowan

1988 Intensive Survey and Limited Testing in the Extended West Cole Uranium Mine, Webb County, Texas. Texas Archeological Research Laboratory, Technical Series 7, The University of Texas at Austin.

Birkeland, P. W.

1984 Soils and Geomorphology. Oxford University Press, Oxford.

Black, S. L.

1989 South Texas Plains. In: From the Gulf to the Rio Grande: Human Adaptation in Central, South, and Lower Pecos Texas, by T. R. Hester, S. L. Black, D. G. Steele, B. W. Olive, A. A. Fox, K. Reinhard, and L. C. Bement, pp. 39-62. Research Series 33, Arkansas Archeological Survey, Fayetteville.

Black, S. L., L. W. Ellis, D. G. Creel, and G. T. Goode

1997 Hot Rock Cooking on the Greater Edwards Plateau: Four Burned Rock Midden Sites in West Central Texas. Review Draft. Studies in Archeology 22, Texas Archeological Research Laboratory, The University of Texas at Austin.

Black, S. L., C. D. Frederick, K. Jolly, J. R Lucas, J. Karbula, P. Takac, and D. R. Potter, with G. Bailey, L. Froelich, and D. Froelich

1997 Archeology Along the WurzbachParkway: Module 3, Investigationand Experimentationat the Higgins Site. Review Draft. Texas Archeological Research Laboratory, University of Texas at Austin.

Black, S. L., J. Karbula, C. D. Frederick, and C. G. Mear

1997 Archeology Along the Wurzbach Parkway: Module 5, Further Testing and GeoarcheologicalEvaluation. Review Draft. Texas Archeological Research Laboratory, University of Texas at Austin.

Blair, W. F.

1950 The Biotic Provinces of Texas. Texas J ournalof Science 2(1): 93-117.

Collins, M. B.

1995 Forty years of archeology in Central Texas. Bulletin of the Texas Archeological Society 66: 361-400.

Cotterell, B., and J. Kamminga

1987 The formation of flakes. American Antiquity 52(4): 675-708. 
Davis, D. R., Jr.

1991 Prehistoric Artifacts of the Texas Indians: An Identification and Reference Guide. Pecos Publishing Co., San Antonio.

Davis, M. W.

1992 Archeological Sites Along the Camino Colombia: A Proposed Toll Road in Webb County, Texas. Hicks and Company, Archeological Series 12, Austin.

Ellis, W. B., and C. Dodt-Ellis

1988 A Cultural Resource Survey and Assessment of the El Mesquite Southeast and $\boldsymbol{O}$ HernProspects, Duval and Webb Counties, Texas. Texas Archeological Research Laboratory, Technical Series 8, The University of Texas at Austin.

Fenneman, N. M.

1938 Physiography of the Eastern United States. McGraw Hill, New York.

Gile, L.H., F.F. Peterson, and R.B. Grossman

1966 Morphological and genetic sequences of carbonate accumulation in desert soils. Soil Science 101: 347-360.

Hall, G. D., T. R. Hester, and S. B. Black

1986 The Prehistoric Sites at Choke Canyon Reservoir, Southern Texas: Results of Phase 11 Archaeological Investigations. Choke Canyon Series 10. Center for Archaeological Research, The University of Texas at San Antonio.

Hester, T. R.

1980 Digging Into South Texas Prehistory. Corona Publishing, San Antonio.

1995 The prehistory of south Texas. Bulletin of the Texas Archeological Society 66: 427-459.

Howells, R. G.

1994 Quick Reference Guide: Freshwater Mussels of the Rio Grande. Heart of the Hills Research Station, Texas Parks and Wildlife Department, Ingram, Texas.

Johnson, L.

1994 The Life and Times of Toyah-Culture Folk, As Seenfrom the Buckhollow Encampment, Site 41K M 16, of Kimble County, Texas. Texas Department of Transportation and the Texas Historical Commission, Austin.

Kibler, K. W.

1996 Results of the Initial Archeological Survey for the Chacon Creek Sewer Interceptor, Webb County, Texas. Letter Report 412, Prewitt and Associates, Inc., Austin Texas. 
MacNeish, R. S.

1958. Preliminary archaeological investigations in the Sierra de Tamaulipas, Mexico. Transactions of the American Philosophical Society, new series, Vol. 48, Part 6.

Maslyk, P., K. W. Kibler, and R. C. Fields

1997 Archeological Site Testing and Additional Archeological Survey for the Chacon Creek Sewer Interceptor, Webb County, Texas. Technical Report 24, Prewitt and Associates, Inc., Austin, Texas.

McGraw, A. J.

1983 Arroyo de los Muertos and Other Prehistoric Terrace Sites Along the Rio Grande, Laredo, Texas. Center for Archaeological Research, The University of Texas at San Antonio, Archaeological Survey Report 106.

McGraw, A. J., and J. Thompson

n.d. Campfires and Ghost Towns on the Rio Grande: The Archeology and History of the Laredo--Colombia Solidarity International Bridge Site. Draft Report, Texas Department of Transportation.

Norwine, J.

1995 The regional climate of South Texas: Patterns and trends. In: The Changing Climate of Texas: Predictability and Implications for the Future, J. Norwine, J. R. Giardino, G. R. North, and J. B. Valdes, eds., pp. 138-154. Geobooks, Texas A\&M University, College Station.

Olson, G. W. (compiler)

1976 Criteria for Making and Interpreting a Soil Profile: A Compilation of the O fficial USDA Procedure and Nomenclature for Describing Soils. University of Kansas Publications, Lawrence.

Prewitt, E. R.

1995 Distributions of typed projectile points in Texas. Bulletin of the Texas Archeological Society 66: 83-173.

Sanders, R. R., and W. J. Gabriel

1985 Soil Survey of Webb County, Texas. United States Department of Agriculture, Soil Conservation Service

Suhm, D. A., A. D. Krieger, and E. B. Jelks

1954 An introductory handbook of Texas archeology. Bulletin of the Texas Archeological Society 25. 
Suhm, D. A., and E. B. Jelks

1962 Handbook of Texas Archeology: Type Descriptions. Special Publication 1, Texas Archeological Society, and Texas Memorial Museum Bulletin 4 (joint).

Turner, E. S., and T. R. Hester

1993 A Field Guide to Stone Artifacts of T a m Indians, Second Edition. Texas Monthly Field Guide Series. Gulf Publishing Co., Houston.

Wormington, H. M.

1957 Ancient Man in North America. The Denver Museum of Natural History, Denver.

Wormser, A. J., and J. W. Clark, Jr.

1992 Archaeological Testing of Four Prehistoric Sites Along FM1472 (Mines Road), Webb County, Texas. Texas Department of Transportation, Austin. 


\section{Appendix I: Backhoe Trench Descriptions}

Trenches were excavated with an excavator (trackhoe) with a 3-foot, smooth bladed bucket. After safety benching (where necessary), all trenches were entered and the walls were scraped to expose the stratigraphy. Stratigraphy was recorded using criteria and terminology outlined in Soil Survey Staff (1990), Olson (1976) and Birkeland (1984). All horizon designations follow conventions outlined in Soil Survey Staff (1990).

\section{WB437}

\section{BT1}

Zone 1: $\quad$ 0-20 cm; fine sandy to silty loam; massive; very friable; strongly calcareous; brown (10YR 4/3); common woody and fine roots; disturbed; few siliceous pebbles; Ap horizon.

Zone 2: $\quad 20-65 \mathrm{~cm}$; fine sandy to silty loam; massive; very friable to friable; strongly calcareous; brown (10YR 4/3); clear irregular boundary; common fine and woody roots; $\mathbf{A B}$ horizon.

Zone 3: $\quad 65-295 \mathrm{~cm}$; stratified silt and loamy silt to silty loam; subtle coarse horizontal stratification consisting of silty loam cut with thin $(5-15 \mathrm{~cm}$ thick) packets of relatively pure, compact silt; silty strata are massive; loamy strata exhibit very weak subangular blocky structure; soft to slightly hard; strongly calcareous; few fine carbonate filaments in loamy strata; silty strata are very pale brown (10YR $7 / 3)$ while loamy strata are brown (10YR 5/3) to pale brown (10YR 6/3); few fine and woody roots; common dispersed charcoal and red sandstone clasts that probably represent isolated burned rocks; common dispersed snail shells; primarily silty loam with thin $(5-15 \mathrm{~cm})$ interbeds of relatively pure silt at $65,110,125,137,155,195$, 220, 235, and $280 \mathrm{cmbs}$; charcoal and sandstone clasts appear restricted to loamier facies above approximately $225 \mathrm{cmbs}$; gradual boundary; BWC horizon.

Zone 4: $\quad 295-330 \mathrm{~cm}$; gravelly loamy sand; massive to stratified; gravel lenses composed of rounded siliceous and subangular sandstone gravel beds in a matrix of loamy sand; light yellowish brown (10YR 6/4); abrupt boundary; C horizon.

Zone 5: $\quad>330 \mathrm{~cm}$; yellowish brown sandstone regolith.

Comments: Represents Unit 2. Contains relatively discrete burned rock/charcoal features at 80 and $180 \mathrm{cmbs}$.

\section{BT2}

Comments: Not Described due to very shallow exposure. Situated immediately adjacent to BT 3. Trenching was discontinued when Feature 1 was located approximately $30 \mathrm{cmbs}$. 


\section{BT3}

Zone 1: $\quad$ 0-20 cm; sandy loam; massive; very friable; strongly calcareous; clear to abrupt wavy boundary; few fine and woody roots; brown (10YR 4/3); disturbed; Ap horizon.

Zone 2: $\quad$ 20-34 cm; sandy to silty loam; massive; very friable; brown (10YR 4/3); strongly calcareous; few fine carbonate filaments; common fine and woody roots; sparse reddened (burned?) sandstone and charcoal flecks near basal contact; Abk horizon.

Zone 3: $\quad 34-56 \mathrm{~cm}$; silty loam to loamy silt; massive; soft; strongly to violently calcareous; few faint mottles representing burrow fills; pale brown (10YR 6/3); contains sparse reddened (burned?) sandstone and charcoal flecks in upper $10 \mathrm{~cm}$; Bk/C horizon.

Zone 4: $\quad$ 56-78 cm; silty loam; massive; soft; strongly to violently calcareous; few distinct brown krotovina; ; one prominent krotovina filled with almost pure gray clay; yellowish brown (10YR 5/4); C horizon.

Zone 5: $\quad$ 78-106 cm; loamy silt; massive; soft; yellowish brown (10YR 5/4); C2 horizon.

Comments: Represents Unit 2. Sparse cultural material (burned rock, charcoal) between approximately 30 and 45 cmbs.

\section{BT4}

Zone 1: $\quad$ 0-15 cm; loamy fine sand; massive, with weak primary color stratification; friable; strongly calcareous; few distinct brownish krotovina and root traces; common woody roots; yellowish brown (10YR 5/4); clear smooth boundary; swale fill; AC horizon.

Zone 2: $\quad$ 15-50 cm; fine sandy loam; massive; friable; strongly calcareous; few faint brownish mottles; dark brown (10YR 3/3); abundant woody roots; smooth gradual boundary; $2 \mathrm{~A}$ horizon.

Zone 3: $\quad$ 50-200 cm; silty loam; weak subangular blocky structure; friable to firm; strongly calcareous; few to common fine carbonate filaments; brown (10YR 5/3); gradual boundary; 2Bk horizon.

Zone 4: $\quad$ 200-290 cm; silty loam; massive; friable to firm; strongly calcareous; pale brown (10Y R 6/3); 2C horizon.

Comments: Represents Unit 2 with a thin veneer of recent material deposited in the swale. Does not exhibit the distinct stratification of silty loams and silts apparent in BT1. Sparse probable cultural material (reddened sandstone clasts and mussel shell) were present in Zone 3 between approximately 70 and $130 \mathrm{cmbs}$. This trench was not examined in detail below $180 \mathrm{~cm}$, as it was backfilled for safety. 


\section{WB438}

\section{BT1}

Zone 1: $\quad$ 0-15 cm; loamy fine sand; massive; very friable; strongly calcareous; gradual boundary; common to abundant fine and woody roots; dark yellowish brown (10YR 4/4) moist; occasional small, subangular sandstone clasts and rounded siliceous pebbles; occasional flakes; probably disturbed; Ap horizon.

Zone 2: $\quad 15-35 \mathrm{~cm}$; loamy fine sand; massive; friable to very friable; strongly calcareous; few faint, fine yellowish and brownish mottles that appear to represent insect burrow fills; common fine and woody roots; clear smooth boundary; dark yellowish brown (10Y R 4/4) moist; occasional small, subangular sandstone clasts and rounded siliceous pebbles; AB horizon.

Zone 3: $\quad 35-60 \mathrm{~cm}$; slightly loamy fine sand; massive; soft; strongly calcareous; gradual boundary; contains multiple generations of large krotovina that give the zone a mottled appearance; color ranges from yellowish brown (10Y R 5/4) to light yellowish brown (10YR 6/4) and light olive brown (2.5Y 5/6) with finer, more distinct dark brown mottles; contains common hard, microcrystalline carbonate nodules with diameters of approximately 0.25-0.5 cm; 2Blk horizon.

Zone 4: $\quad 60 \mathrm{~cm}$-approximately $200 \mathrm{~cm}$; slightly loamy fine sand; massive; soft; strongly calcareous; gradual boundary; light olive brown (2.5Y 5/6); contains common hard, microcrystalline carbonate nodules with diameters of approximately $0.25-0.5 \mathrm{~cm} ; 2 \mathrm{~B} 2 \mathrm{k}$ horizon.

Zone 5: approximately $200-290 \mathrm{~cm}$; slightly loamy fine sand; massive; soft; strongly calcareous; gradual boundary; light olive brown $(2.5 \mathrm{Y} 5 / 6) ; 2 \mathrm{C}$ horizon.

Comments: Represents Unit 1 overlain by approximately $35 \mathrm{~cm}$ of Unit 2 . No cultural material except in disturbed surface horizon. Description below $1.5 \mathrm{~m}$ was made by examining the profile at a distance during excavation.

\section{BT2}

Zone 1: $\quad$ 0-7 cm; sandy loam to loamy fine sand; weakly stratified; very friable; strongly calcareous; clear boundary; common flakes; color varies from brown to yellowish brown; represents recent slopewash; AC horizon.

Zone 2: $\quad$ 7-20 cm; fine sandy loam; massive; very friable to friable; strongly calcareous; clear smooth boundary; dark brown (10Y R3/3); common fine roots; $2 \mathrm{~A}$ horizon.

Zone 3: $\quad$ 20-30 cm; fine sandy loam; massive; friable; few faint brownish mottles; clear smooth boundary; few fine carbonate filaments; brown (10YR 4/3); sparse unburned rocks at lower contact; few fine roots; $2 \mathrm{AB}$ horizon.

Zone 4: $\quad 30-60 \mathrm{~cm}$; fine sandy loam; weak fine subangular blocky structure; soft to slightly hard; strongly calcareous; common fine, faint to distinct mottles representing primarily root traces and insect krotovina; brown (10YR 5/3) 
Zone 5: $\quad 60-72 \mathrm{~cm}$; loamy to silty fine sand; massive to very weak subangular blocky structure; soft; strongly calcareous; few faint brownish mottles; pale brown (10YR 6/3); few fine carbonate filaments; smooth, clear boundary; $2 \mathrm{C} 1$ horizon.

Zone 6: $\quad$ 72-100 cm; loamy fine sand; massive; soft; few fine roots; pale brown (10YR 6/3); strongly calcareous; common fine faint brownish mottles; few fine carbonate filaments; smooth, clear to gradual boundary; $2 \mathrm{C} 2$ horizon.

Zone 7: $\quad$ 100-110 cm; loamy fine sand; massive; soft; few fine roots; pale brown (10YR 6/3); strongly calcareous; few fine, faint brownish mottles; few fine carbonate filaments; clear, irregularly dipping boundary representing unit contact; 2C2 horizon.

Zone 8: $\quad$ 110-135 cm; gravelly to very gravelly loamy sand; massive; soft; few fine roots; strongly calcareous; brownish yellow (10YR 6/6); few faint brownish mottles; few medium carbonate nodules; contains subhorizontal concentrations of stream gravel; 3Bk horizon.

Comments: This trench contains the lateral contact between Unit 1 and the onlap of Unit 2, and is overlain by a thin veneer of very recent slopewash. Cultural material was confined to surface veneer.

BT3

Zone 1: $\quad$ 0-10 cm; loamy fine sand; massive; very friable; strongly calcareous; clear boundary; represents veneer of recent slopewash; $\mathrm{C}$ horizon.

Zone 2: $\quad$ 10-40 cm; fine sandy loam; massive; very friable; strongly calcareous; few faint, fine yellowish and brownish mottles; common fine and woody roots; clear smooth boundary; dark yellowish brown (10YR 5/3) dry; sparse cultural material; $2 \mathrm{Ab}$ horizon.

Zone 3: $\quad 40-110 \mathrm{~cm}$; silty loam; weak subangular blocky structure; soft to slightly hard; strongly calcareous; clear to gradual boundary; pale brown (10YR 6/3); common faint mottling representing burrow fills; contains at least three zones of disrupted desiccation peds developed in silty clay drapes; clear wavy boundary; 2BC horizon.

Zone 4: $\quad$ 110-190 cm; loamy fine sand; massive; very friable to friable; moderately to strongly calcareous; light olive brown (10YR 6/6); contains common carbonate filaments and common hard, microcrystalline carbonate nodules with diameters of approximately $0.25-0.5 \mathrm{~cm}$ below $180 \mathrm{~cm}$; 3Bk horizon.

Comments: Represents Unit 1 successively draped with approximately $1 \mathrm{~m}$ of Unit 2 and $10 \mathrm{~cm}$ of recent slopewash. Contains sparse cultural material to a depth of $30-40 \mathrm{~cm}$. 
BT4

Zone 1: $\quad$ 0-40 cm; loamy fine to medium sand; massive; very friable; strongly calcareous; clear to abrupt boundary; dark yellowish brown (10YR 4/6); irregular to broken boundary; represents veneer of recent spoil; $\mathrm{C}$ horizon.

Zone 2: $\quad 40-50 \mathrm{~cm}$; fine sandy to silty loam; massive; very friable to friable; strongly calcareous; few faint, fine yellowish and brownish mottles; few fine and woody roots; clear smooth boundary; dark brown (10YR 3/3) dry; $2 \mathrm{Ab}$ horizon.

Zone 3: $\quad$ 50-110 cm; fine sandy loam; weak subangular blocky structure of probable biogenic origin; slightly hard; strongly calcareous; clear to gradual boundary; brown (10YR 5/3); common distinct brown and yellow mottling representing burrow fills; gradual to diffuse boundary; few fine roots; contains at least two subhorizontal zones of somewhat siltier sediment; 2Bw horizon.

Zone 4: $\quad$ 110-140 cm; fine sandy loam; weak blocky structure; slightly hard; strongly calcareous; brown (10YR 5/3); common carbonate filaments; clear wavy boundary; 2Bk horizon.

Zone 5: $\quad$ 140-190 cm; fine to medium loamy sand; massive; friable; moderately to strongly calcareous; few distinct, fine to medium mottles representing burrow fills; brownish yellow (10YR 6/6); common carbonate filaments and a few hard nodules below $180 \mathrm{~cm}$; $3 \mathrm{Bk}$ horizon.

Comments: Represents Unit 1 successively draped with approximately $1 \mathrm{~m}$ of Unit 2 and $40 \mathrm{~cm}$ of recent spoil. Contains sparse cultural material, including a few flakes and a mussel shell; from $80-100 \mathrm{~cm}$.

\section{REFERENCES CITED}

Birkeland, P. W.

1984 Soils and Geomorphology. Oxford University Press, Oxford.

Olson, G. W. (compiler)

1976 Criteria for Making and Interpreting a Soil Profile: A Compilation of the Official USDA Procedure and Nomenclature for Describing Soils. University of Kansas Publications, Lawrence.

Soil Survey Staff

1990 Keys to Soil taxonomy (fourth printing). SMSS Technical Monograph 19. Soil Management Support Services, Virginia Polytechnic Institute and State University, Blacksburg, VA. 